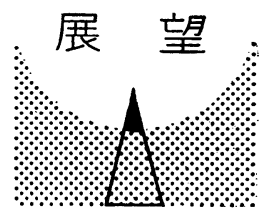

\title{
動力測定の現状と将来の動 向"
}

\section{1. まえがき}

原動機製造業者はその出力を知るため試験台上で吸 収動力計による制動試験を行ない，使用者は使用状態 で伝達動力計によりその出力を測っている. 同じ原動 機でも, 試験台上の場合と現場使用状態の場合では一 般に条件が異なる。したがって，原動機と受動機との エネルギ伝澾はそれぞれの試験を行なわなければ完全 とはいえない，特に，その振動特性はまったく異なる ものと考えてさしつかえない.このように動力測定は 測定場所・測定対象・測定装置などにより，それぞれ 異なった結果が出てくるので必ずしも一致するとは限 らない：この際たいせっなことは, 測定の基準が何か ということである. なお, 動力という言葉を狭い意味 に解釈して, ここでは, 回転機の動力測定について述 べる.

\section{2. 動 力 計}

内燃機関, 蒸気機関, 水車などの原動機で発生した 動力および推進器, 発電機, 電動機, ポンプ, 送風機, 圧縮機などの作業機で消費する動力の大きさを測定す ることが必要であるが，この動力を測定する装置を動 力計といら．動力はそれを伝達する軸の回転力と回転 速度とを測定すれば，その積に比例することにより決 定されるが, 回転速度は回転計により測定できるので, 動力計 (dynamometer) といらと, 単に回転力のみを 測定する回転力計 (torquemeter) またはねじりを測定 するねじり計（torsion meter）をさす場合が多い.

動力計は測定の際に動力を制動し, 吸収するか吸収 しないかにより, 吸収動力計と伀達動力計とに分けら れる。

吸収動力計は測定する動力を制動して熱または電気 のエネルギに変えて吸収する動力計であるから，この 動力計を使用して測定する場合は全部制動されて損失 となるので，運転中の伀達動力を損失なく測定するこ とは不可能である.これに反して,伝達動力計は動力を

*原稿受付 昭和 42 年 7 月 7 日

**正会员, 東京都立大学工学部（東京都世田谷区深沢町 1 の950) 伊＼cjkstart潔*

伝える伝達軸のねじり角, あるいは伝達歯車の歯に作 用する反動力を測定して回転力を求めるものであるか ら，測定の際の動力の損失はほとんどない，したがっ て，機械を運転している状態で常に動力の測定ができ る. 吸収動力計において回転力を測定する方法は原動 機あるいは動力計のいずれかの枠組を伝達軸のまわり に摇動するように取付け, その受ける回転力をてこの 長さと重錘の重さとの積によって求めるのが普通であ る.

\section{1 吸收動力計}

2.1.1 固体摩擦動力計 固体摩擦を利用して制 動し, 動力を吸収する動力計である. 固体摩擦力は横 圧力が一定ならば速度に無関係に一定であるため, 回 転速度が変化したとき，それを防止するょうに，制動 力が変化しないのが久点である.

(a) プローニ動力計 (プローニブレーキ) (b) ロープ ブレーキの二種がある.

2.1.2 水動力計 水を満たしたケーシング内で 回転体を回転し，水の与える摩擦抵抗によって動力を 制動して熱に変える.ケーシングを回転軸のまわりに 摇動できるようにして, その回転力および回転速度を 測定すれば動力を決定できる．回転体により，(a)円板 形，(b)ユンカース，(c)フロードの三種の水動力計があ るがフロードが多く用いられる．回転力の測定にあた りてこの長さと重錘の重さの測定から考えて，精度は $2 \%$ ぐらいである.

2.1.3 空気動力計 羽根動力計ともいい, 羽根 あるいはプロペラを空気中で回転する場合の抵抗によ り動力を制動吸収する動力計である．構造が簡単で高 速度の場合に小形で大動力を吸収するので航空機の試 験に多く用いられ，自動車のエンジン試験にも用いら れる. 羽根の形に制限はなく, 長方形板を棒に取付け たものをはじめ種々ある.

2.1.4 電気動力計 電気動力計は特別の構造の 発電機で，その回転子を原動機で回転すると電力を発 生し, 動力が吸収され電気エネルギに変えられる. 交 流式と直流式とがあり, いずれも回転子に作用する回 転モーメントを測定する. 回転子の空気に対する摩擦 
およびブラシと整流子との摩擦などは計測の際十分注 意する必要がある. 発生する電流および電圧を測定し て出力を決定し, 発電機の効率あるいは損失を別に求 めれば，この二つの值から発電機を運転する原動機の 出力を決定することができる. 発電用蒸気タービンや 水車の場合などは従来この方法により動力測定を行な ってきたが，実際の発電機の効率あるいは損失は実測 できないので問題がある.

\section{2 伝達動力計}

吸収動力計は測定する動力を全部吸収してしまうか ら動力の消費をともない，大きな動力を低速度の回転 で吸収するよらな場合には動力計が非常に大きくなり 高価となるうえに, 制動により発生した多量の熱を放 散させるのに困難をともなう．特に原動機の出力を運 転状態において常時計測したい場合には伝達動力計が 必要となる。

2.2.1 ねじり動力計原動機より中間軸を経て 動力が伝達される際，軸のねじり角を測定して回転力 を測定する. 回転速度を同時に測定し，これらの積を 求めればねじり動力が求められる. 3 に詳説する.

2.2.2 遊星歯車式動力計 原動機の軸に固定し た歯車とかみ合ら遊星歯車により回転モーメントを測 定すれば伝達動力を測定できる. 平歯車式とかさ歯車 式とがある. 航空発動機の馬力の測定に使用されてい る.

\section{3. ねじり動力計}

原動機の出力および作業機の入力がわかれば効率が 明らかとなる，発電所ならば水車や発電機の効率が明 らかとなり，船ならば主機，推進機および船体などの それぞれの性能が明らかとなり，船全体の優劣を検討 する資料が得られる.

\section{1 ねじり動力計の展望(1) (12)}

つぎのように各種のねじり動力計が多くの人々によ り考案ないし設計製作された，年代順に示し，かっこ 内溌明発表年である.

$\begin{array}{ll}1 & \text { Ayrton-Perry } \\ 2 & \text { Fischinger } \\ 3 & \text { Jervis-Smith } \\ 4 & \text { Gaiffe-Günther } \\ 5(\mathrm{a})(\mathrm{b})(\mathrm{c}) & \text { Föttinger } \\ 6 & \text { Denny-Johnson } \\ 7 & \text { Hopkinson-Thring } \\ 8 & \text { Webb } \\ 9(\mathrm{a})(\mathrm{b})(\mathrm{c}) & \text { Denny-Edgecombe } \\ 10 & \text { Brevis-Gibson }\end{array}$

\begin{tabular}{|c|c|}
\hline 11 & Collie \\
\hline 12 & Barr-Stroud \\
\hline $13(a)(b)$ & Drysdale \\
\hline $14(a)(b)$ & Amsler \\
\hline 15 & Moore \\
\hline 16 & Gary-Cumming \\
\hline 17 & Lux \\
\hline $18(a)(b)(c)$ & Nettmann \\
\hline 19 & Kinter \\
\hline 20 & Görges-Weidig \\
\hline $21(\mathbf{a})(\mathrm{b})(\mathrm{c})$ & Vieweg-Wetthauer \\
\hline 22 & Bauersfeld \\
\hline 23 & 末 広 \\
\hline 24 & Frahm \\
\hline 25 & Keinath (Siemens-Halske) \\
\hline 26 & Batson-Hyde \\
\hline 27 & Elässer \\
\hline 28 & Krupp \\
\hline 29 & Moullin \\
\hline 30 & Klein \\
\hline 31 & $\begin{array}{l}\text { Ford (Siemens-Ford, } \\
\text { Mc Nab-Ford) }\end{array}$ \\
\hline 32 & Parker-Jackman \\
\hline 33 & Hoppe-Maihak \\
\hline 34 & 小 林 \\
\hline 35 & Morin \\
\hline 36 & 金 尾 \\
\hline 37 & Gramberg \\
\hline 38 & 研 野 \\
\hline 39 & 松 本 \\
\hline 40 & 浜 部 \\
\hline 41 & Müller \\
\hline 42 & 瀬＼cjkstart藤 \\
\hline 43 & 近 藤 \\
\hline $44(a)(b)$ & White-Fox \\
\hline 45 & Siemens-Halske \\
\hline $46(a)(b)$ & General Electric \\
\hline 47 & 海老原 \\
\hline 48 & Naval Research Laboratory \\
\hline 49 & Westinghouse \\
\hline 50 & 日立造船 \\
\hline $51(a)(b)$ & 伊 丹 \\
\hline $52(a)(b)$ & 三菱重工業神戸造船所 \\
\hline 53 & 三菱重工業長崎造船所 \\
\hline 54 & Muirhead \\
\hline 55 & 三井造船 \\
\hline
\end{tabular}

(1908)

(1908) 


\section{(1) Ayrton-Perry 式ねじり動力計 ${ }^{(5)}$}

小動力測定に考案したもので，ねじり角増大のため 軸を切断し，図 1 のようにスプリングで連結する．軸 の一端には円板，他端には半径方向に腕を取付け，腕 の先端は円板の周に一端を固定した棒と結ばれてい る. その結び方は棒の軸方向に自由に動きうるように なっている. 動力伝達の場合は腕が円板に対し円周方 向に動くことにより，棒の先端 の目印が半径方向に動く、した がって，目印がえがく円の半径 が変化するから，これを観測し て動力を測定する. しかし回転 によって作られる円の半径を測 定することは困難で不正確であ る.

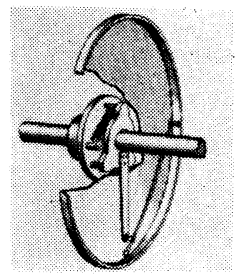

図 1 Ayrton-Perry 式ねじり動力計

（2） Fischinger 式ねじり動力計 ${ }^{(4)(13)}$

図 2 において $\mathrm{S}_{1}, \mathrm{~S}_{2}$ は 2 個の滑車で $\mathrm{S}_{1}$ は動力を 受け, $\mathrm{S}_{2}$ は動力を伝達する. $\mathrm{S}_{1}, \mathrm{~S}_{2}$ はてこ $\mathrm{a} b$ で 連結され $\mathrm{a} \mathrm{b}$ は受け $\mathrm{A} ， \mathrm{~B}$ で支えられている。 $\mathrm{B}$ が下

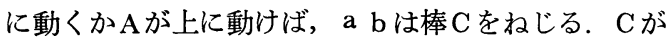
ねじれると d が c のまわりにまわり，eがいっしょに 動くからe の下端の軸と同心の棒 $\mathrm{f}$ は軸方向に移動す る. したがって, 平衡装置 $\mathrm{L}, \mathrm{G}$ で $\mathrm{f}$ を元の位置にも どす．Zを零にするときのGが回転力を示す.

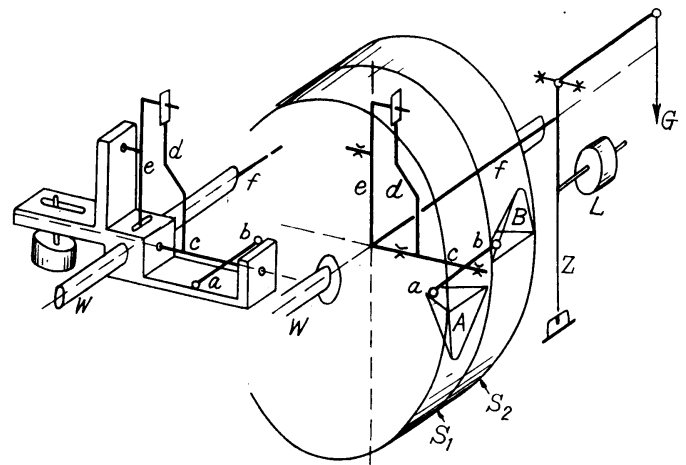

図 2 Fischinger 式ねじり動力計

(3) Jervis-Smith 式ねじり動力計 (14)

図 3 のように 2 個の絶縁性円板 $\mathrm{A} ， \mathrm{C}$ を軸に取付け

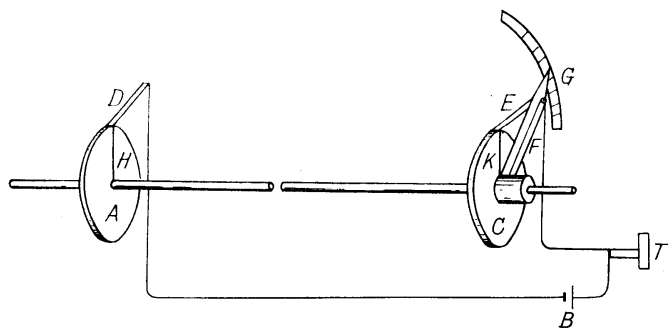

図 3 Jervis-Smith 式ねじり動力計
細い電線 $\mathrm{H} ， \mathrm{~K}$ 半径方向に付ける. $\mathrm{H}, \mathrm{K} か ゙$ 同一平 面上にあれば軸の一回転ごとに受話器 Tに 1 回音が聞 えるが，軸がねじれれば音は聞えない，再び音が聞え るようにブラシ保持器 $\mathrm{F}$ を調整することにより目盛板 $\mathrm{G}$ 上にねじり角が求められる.

(4) Gaiffe-Günther 式ねじり動力計 ${ }^{(5)}$

図 4 のように軸を切断，スプリングによりねじり角 を増大している． 2 枚の円板の周を導体と絶縁物とに 分け，ブラシ周辺に接触している. 図のような回路を 作り電圧を加え, 流れる電流の值からねじり角を知る. 同時に二つのブラシが導体に接触している間は，ねじ り角によって変ることを利用している.

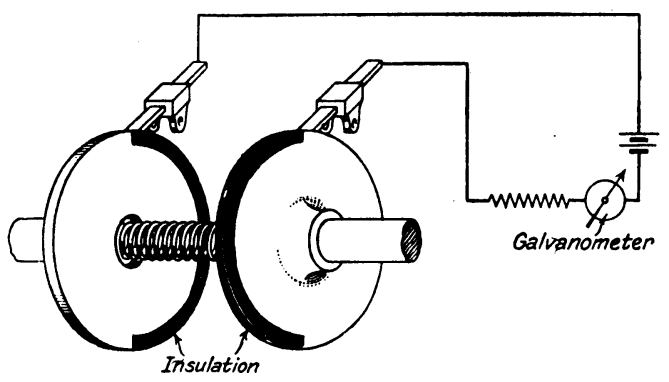

図 4 Gaiffe-Günther 式ねじり動力計

(5) Föttinger 式ねじり動力計 ${ }^{(15)(16)}$

(a) 図 5 のようにスリーブの端に円板を取付けた構 造で, 拡大装置としてリンクの組合せを使用し, ねじ り角を軸方向の変位に変え，10倍くらいの拡大を行な っている，目盛読みもできるが,招もに記録で, 回転軸 と同心で，軸に対して静止している円筒に紙を巻き， 指針の先にペンを付け, 軸の一回転の回転力の変動が 記録される. 用途は船舶の軸馬力で商品として製作さ れた.

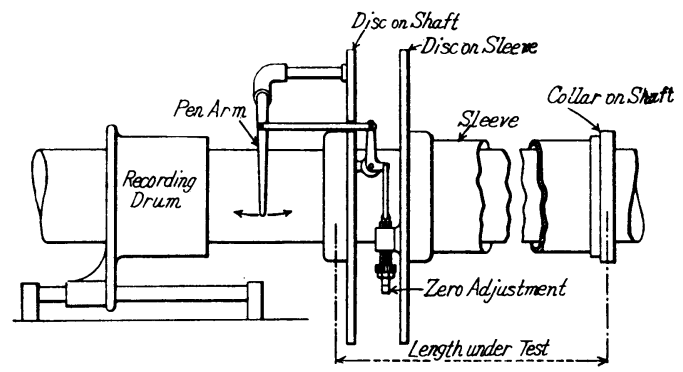

図 5 Föttinger 式ねじり動力計（a）

(b) 図6のように，円周上等間隔にスリットのある 円板 2 枚が向合っている. その両端に光源と光点を投 じる目盛板が向合って，軸方向に光を通し，目盛板の 霧点に光点が写る. 回転力がかかるとスリットがずれ て軸方向からはずれた方向に光点を生じるから，その 位㯰によって回転力が求められる. 


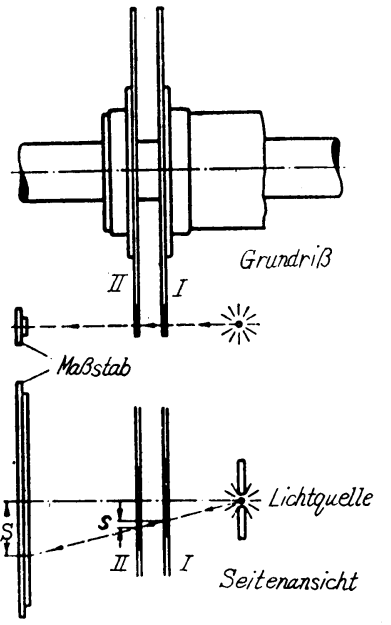

図 6 Föttinger 式ねじり動力計 (b)

(c) 図 7 のように軸上ある距離の 2 個の円筒に问時 に印を打ち, その位置を比較してねじり角を測定する. 点続的に変化を記録することができる，1回転の記録 のみである. 同時に印を付けるために, 音さ振動, 電 気火花，同期電動機などが利用されている.

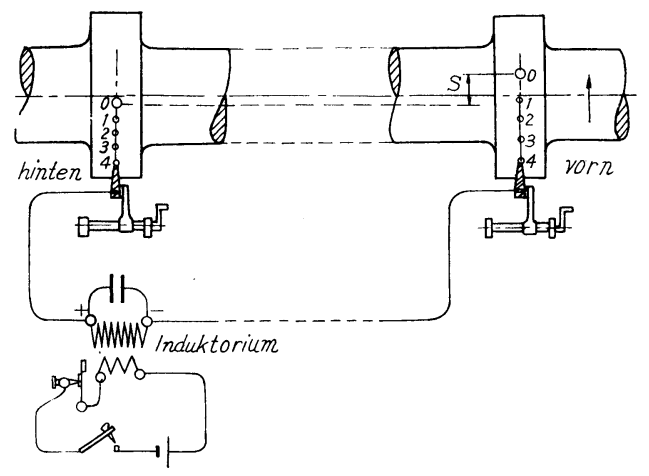

図 7 Föttinger 式ねじり動力計 (c)

(j) Denny-Johnson 式ねじり動力計(17) (19)

図 8 のように軸上ある距離に 2 枚の円板を置き, 半 径方向に棒形永久磁石を取付け, その磁束を切るよう に軸外に電機子巻線を㯰き, その誘導電圧を受話器に 入れて零点検出により軸上 2 点のねじり角を知る. 電 機子巻線には円周上に移動するマイクロメーターがあ り, 受話器の音を零にするように調節する.

(7) Hopkinson-Thring 式ねじり動力計(20) (24) 特別な測定用軸を用いないで，一定 2 断面間のねじ り角を光てこにより昖大測定して回転力を求める装置 である．㕯 9 のようにスリーブ式で反射平面鏡 C が軸 に垂㨁な軸のまわりに回転できるようになっていて， 動力伝達の際リンクの組合せでねじり角に比例して平 面鏡が回転する．軸からある距離の光源から光を投射
し反射鏡により反射し，目盛ガラス板 $\mathrm{G}$ 上に像が映じ ねじり角が測定される. トルク倍率も大きく, 構造堅 固で測定も容易なので, 現在船舶推進軸のねじり測定 用として広く使用されている. 東京計器のポップキン ソントーションメーターはこれである。しかしこのお 法はねじり振動のあるディーゼルエンジンでは使用で きない.タービンェンジンでも光の像は安定していな い.しかもプロペラの羽根のどの方向をはかるかによ り值は異なるので使用上の注意がいる.

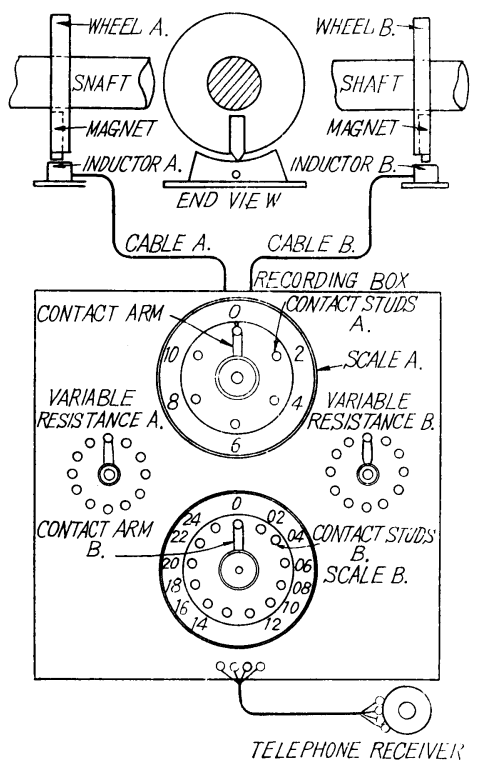

汹 8 Denny-Johnson 式ねじり動力部

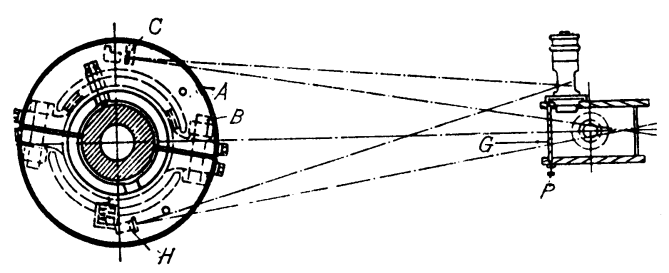

図 9 Hopkinson-Thring 式ねじり動力詮

(8) Webb 式(6)(25)

図10のように軸上ある距離に 2 枚の誘導子突起の円 板 I, II を置き, 相対する電機子巻線に電圧を誘導さ せる. 電機子巻線を円周上に移動して受話器で聞き零 点を検出し，その移動量からねじり角を測定する.

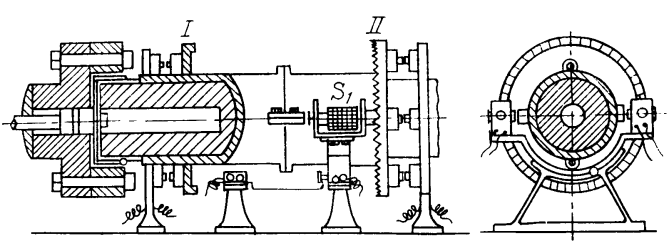

図10 Webb 式ねじり動力計 
（9） Denny-Edgecombe 式ねじり動力計 ${ }^{(26) ~(29) ~}$

(a) 図11のようにスリーブの端に半径方向に延びた 腕が付いていて, 歯車の組合せによりねじり角を拡大 して，綱をかけた車輪を回転させる，綱の先には軸の 方向に動く軽い円筒がスリーブの上にはめてあり，車 輪の回転により円筒が移動する。円筒の移動量を特殊 のものさしで測る、読みは指針に現われまたは記録装 置に記録される．ものさしと軸とはローラで接触する 構造で, ものさしは測定時以外は軸から離れている.

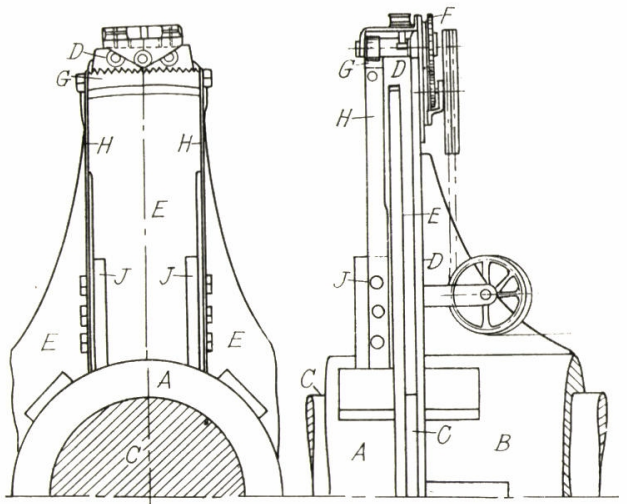

図11 Denny-Edgecombe 式ねじり動力計（a）

(b) 機械光学的検出方法でスリーブ形である. 軸の ねじり角をてこと歯車によって, 小円板の回転に変え る装置が図12のようにスリーブの上に取付けてある. 小円板上の目盛は軸 1 回転 1 回ストロボスコープ式に 測定される.

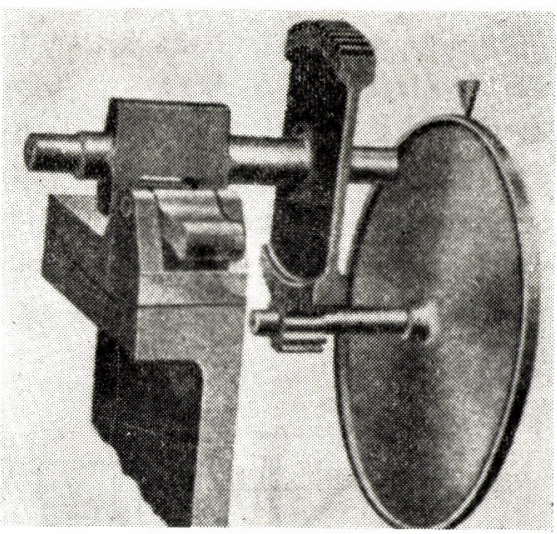

図12 Denny-Edgecombe 式ねじり 動力計 (b)

(c) 電圧降下を利用したもので, 図13のようにスリ 一ブに円板を取付けた構造である。 円板の周囲にスリ ップ抵抗体を取付け，ねじり角に比例してブラシがそ の上を移動する，スリップリングにより抵抗体に電流 を流しブラシの位置により起こる差電流により指針を 動かす．指針は慣性により平均值を示す.

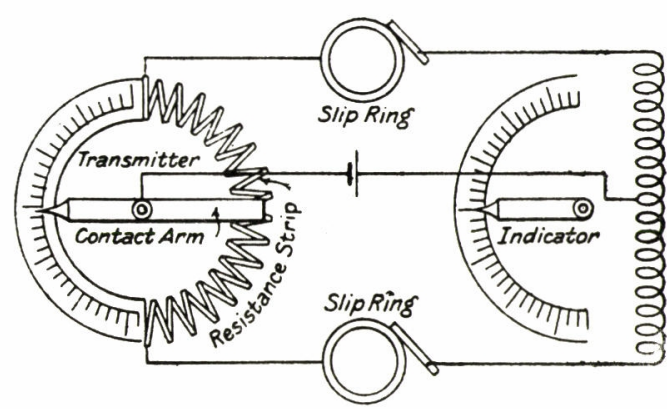

図13 Denny-Edgecombe 式放じり動力計 (c)

(10) Brevis-Gibson 式ねじり動力計 ${ }^{(26)(30) ~(32) ~}$

5 (b) と同原理で 2 個のスリットの相互移動によって 光の進路を変える方式である。構造は図14のように, スリーブが両方から同じ長さで出ていて, その端に同 じ円筒が付いている．2，個の同心円筒には軸と平行に スリットがあり, 内部円筒のなかに軸から離れて光源 がある.観測装置を軸のまわりに移動させ,スリットを 通る光が見えるとき,その移動量からねじり角を知る。

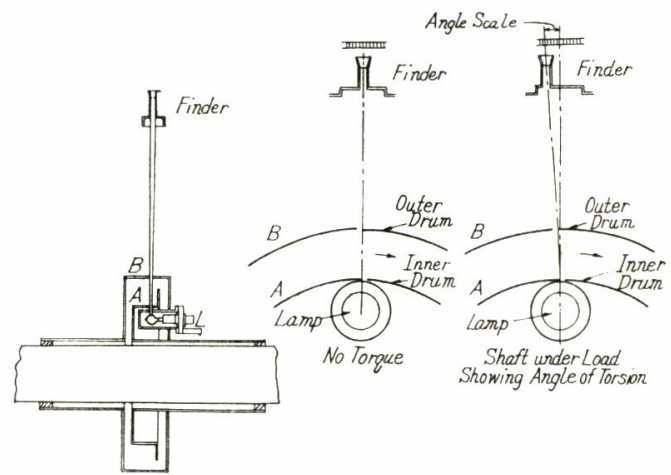

図14 Brevis-Gibson 式ねじり動力計

(11) Collie 式ねじり動力計(20)(21)(31)(33)

軸の内部に図15のようにねじり角を伝達する細い中 間軸が入っていて，一端を軸に他端を軸のまわりの円 板に取付ける. その円板と軸に固定した円板の間には 互いにある角度をもったスリットがあり，2 個のスリ ットによる光の像の長さの変化によってねじり角を測 定する.

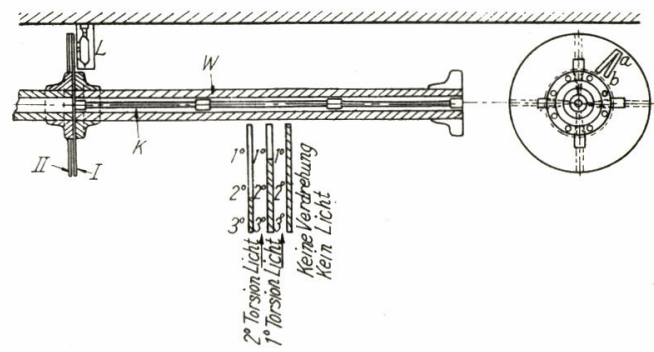

図15 Collie 式㸚じり動力計 
(12） Barr-Stroud 式ねじり動力計 ${ }^{(6)(34)}$

回転円板の周辺を多数の導体と絶縁物とに分け，ブ ラシに電圧を加えれば矩形波の電流となる．軸上の 2 点に円板を取付け，図16のようにブラシを直列にして 電圧を加えれば電流はねじり角を示す．計器は慣性の ためねじり角の平均值を示す.

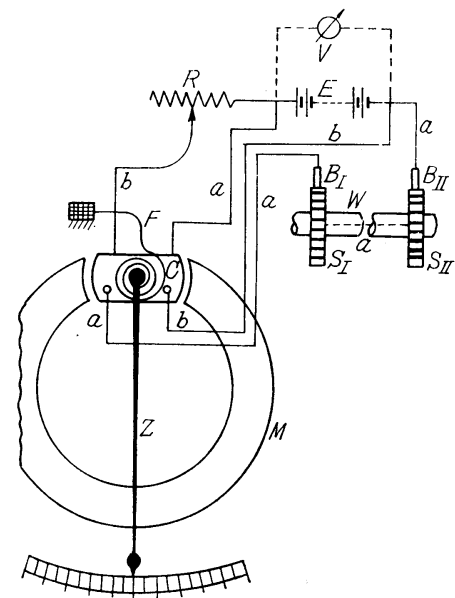

汶16 Barr-Stroud 式ねじり動力計

(13) Drysdale 式ねじり動力計 ${ }^{(5)}$

(a) 図17のようにスプリングによって連結し，単相 発電機のブラシの位置をねじり角に比例して変化させ 馬力を直読する方式である，さらに值流発電機を利用 し，ねじり角によりブラシを移動させ発生電圧を変化 させる方式などが考えられた.

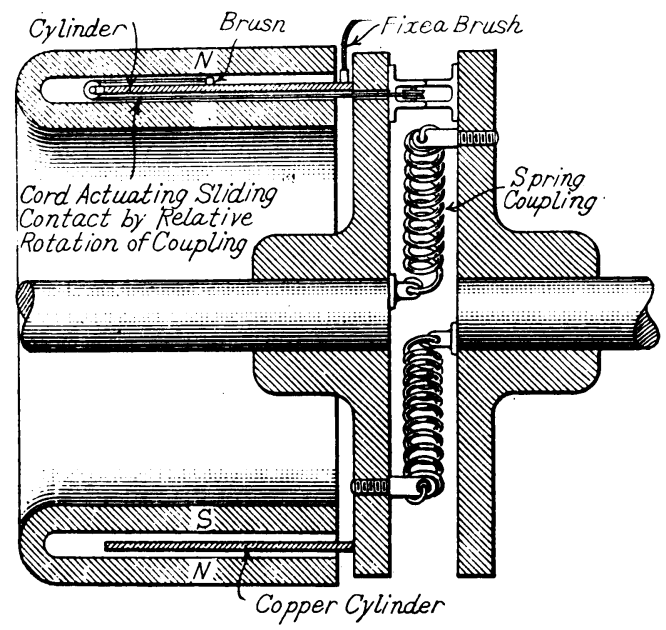

図17 Drysdale 式ねじり動力計（a）

(b) 図18のように板スプリングで軸で結び，両側に 誘導子形交流発電機を置き，棒磁石で励磁する．誘導 子を付けた軸の回転により電機子巻線には回転速度と 誘導子の数により，一定周波数の交流起電力を誘導す
る. 両電圧はねじり角に比例した位相差を生じるから 動力を測定できる. 棒磁石, 電機子巻線の静止部分と 軸との間は軸受によって摩擦を少なくし空隙が変化し ないようにしてある。

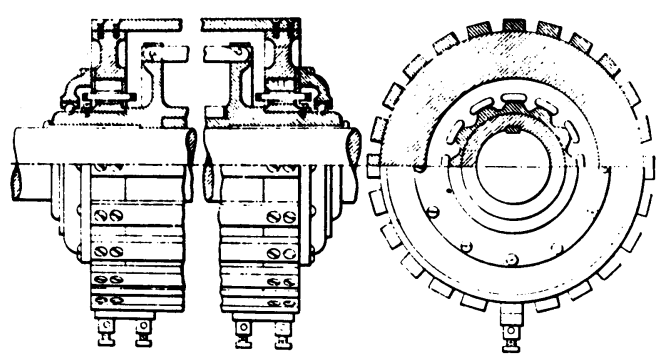

因18 Drysdale 式放じり動力計（b)

(14) Amsler 式ねじり動力計 ${ }^{(5)(35) ~(37) ~}$

(a) 図19のようにスリーブの端に目盛があり，ねじ り角による目盛とそれに対する標線間の移動を読む. その方法に電気火花を利用する．周囲を暗くして，軸 の回転と同期的に回路を開閉して, 電気花火が飛ぶよ らにすれば，その明滅により目盛が静止して読める. 火花の飛ぶ位置は接触子の位置により調整できる。

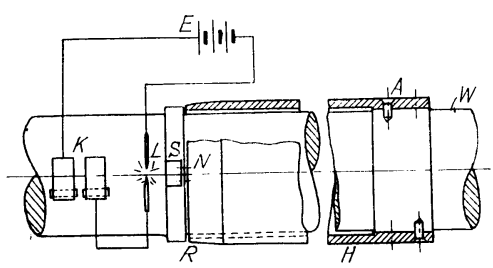

図19 Amsler 式ねじり動力計 (a)

(b) スリットを通して軸上の目盛を直読する方式で 小さなねじり角は読みにくい. したがって, 図20のよ らに細い中間軸を使用し, さらに円板を使用し直径を 大きくして偏位を増大している．回転中軸上の目盛が 読める. 構造はスリーブの端のスリットのある円板に 目盛が相対し, その背後に光源ランプがあり, 視差を 除くためにスリーブの上にもう 1 枚のスリットのある 円板を取付ける。

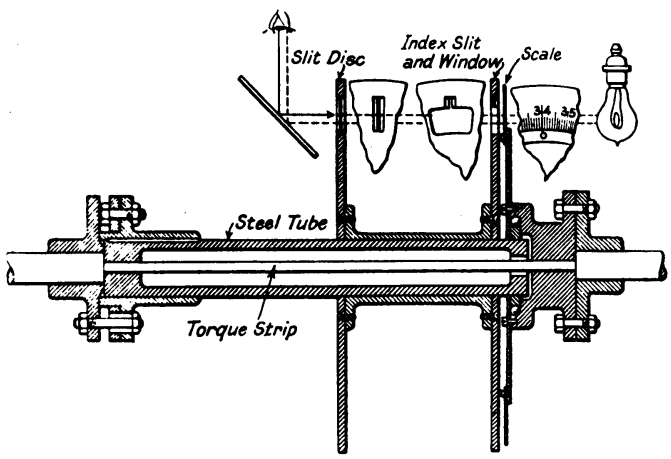

図20 Amsler 式ねじり動力計 (b) 
(15） Moore 式ねじり動力計 ${ }^{(38)}$

スプリングのねじり角を電気的に測定する方法で, 図21に示すように 2 台の単相交流発電機を使用する. 誘導電圧は正弦波で，軸に伝達動力がなくスプリング がねじれないときは反対の位相になるようにすれば， 出力電圧は回転力と速度との積に比例し, したがって 電圧計の読みはただちに伝達動力を示す.

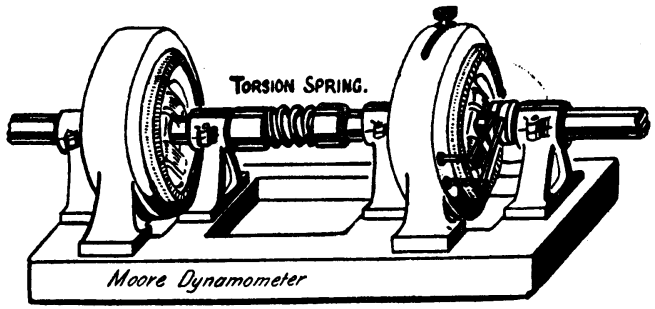

図21 Moore 式ねじり動力計

(16) Gary-Cumming 式ねじり動力計 ${ }^{(39)(40)}$

図22のようにねじり角を伝達する機械的構造が軸の 内部にあり，構造が小さいので，軸は曲げおよび振動 に対する影響が少ない，軸の内部の一端を固定し，自 由な他端には軸の半径方向に棒があり，その先が軸表 面に偏位を示す，偏位はてこの作用により軸と平行と なり，針により軸表面に記録される，零点を同時に記 録してその間隔が叔じり角を示す.

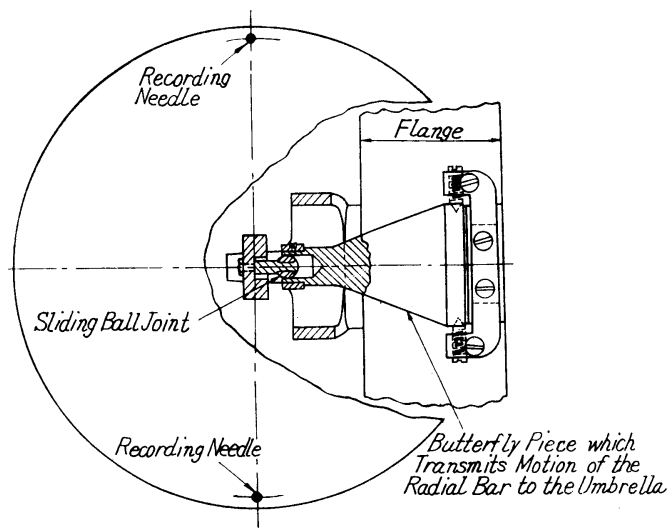

図22 Gary-Cumming 式ねじり動力計

（17）Lux 式ねじり動力計 ${ }^{(41)}$

図23のように軸に直角に火花を飛ばす針があって軸 とともに回転する. その先端の書く半径の外側には円 環があって 2 カ所で絶縁されていて 1 回転ごとに電流 が流れ, 継電器の作用により記録円筒上に記録される。

(18) Nettmann 式ねじり動力計 ${ }^{(1)(6)(10)(42)}$

(a) 図24のようにねじり角による腕の端の偏位を車 輪の回転に変える．車輪に綱をかけ，記録指針を軸と 直角に上下寸る，記録円筒は軸から離れ，歯車により

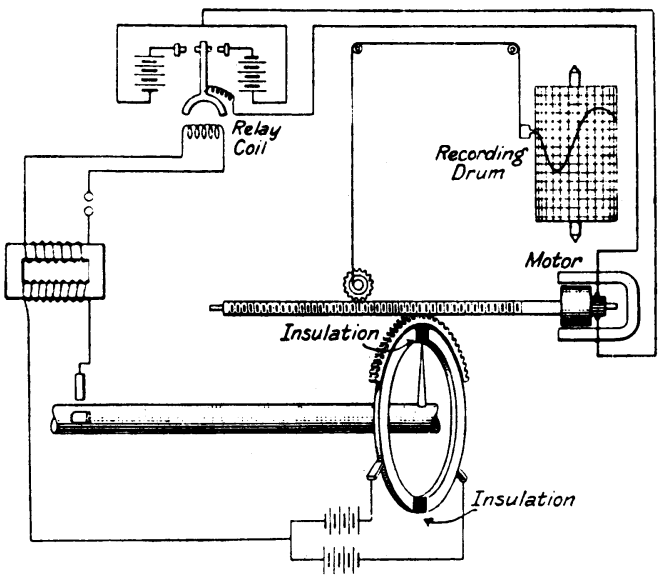

図23Lux式ねじり動力計

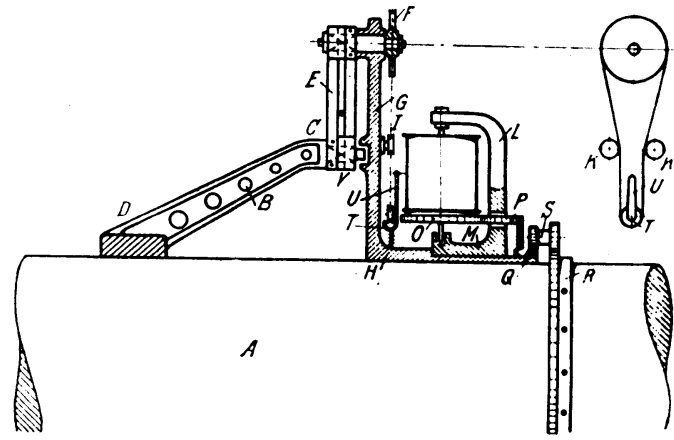

図24 Nettmann 式ねじり動力計（a）

低速度で回転する.

(b) 図25のように投射光の目盛を暗箱に入れ，目盛 像はレンズを通しすりガラス上に写る．光の進行方向 を回転と同期して換え，目盛面を断続明滅させる。

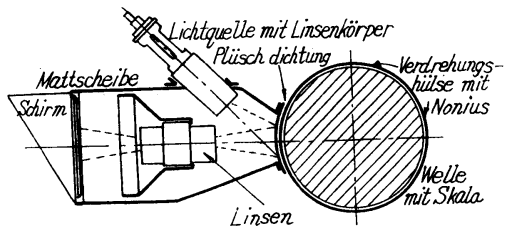

図25 Nettmann 式ねじり動力計 (b)

(c) 図26のように 1 対の円板におのおの接点があり それに対応して軸外にも接点を置き，その接触が同時 に行なわれるように接点を移動させてねじり角を知る

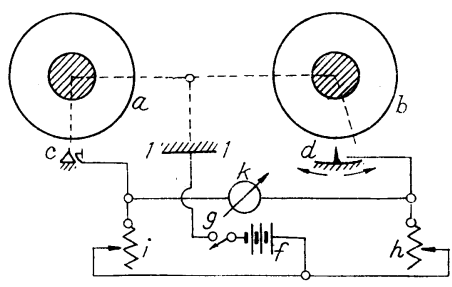

図26 Nettmann 式ねじり動力計（c） 
(d) 図27のように軸上の 2 点にゴールドシュミット 発電機 2 台をおき，出力電圧より動力を直読する．軸 に值結した交流発電機により，その 1 次巻線を励磁す る. 2 次側に発生する電圧の差を交流電圧計に加える. 電機子の前を鉄心が通過する位相により電圧が変わり 電圧計は動力を示す.

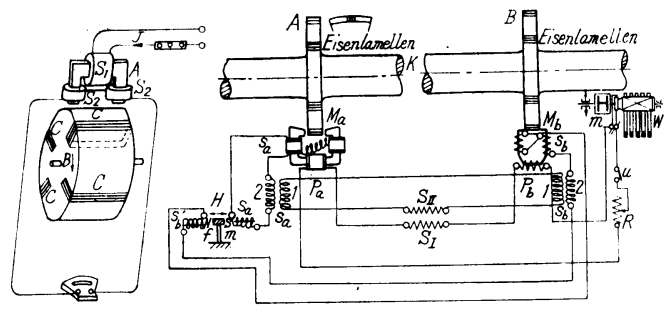

図27 Nettmann 式秝じり動力計 (d)

(19) Kinter 式ねじり動力計 ${ }^{(5)}$

14(a)と同じ原理で図28のようにスプリングにより权 じり角を増大し，目盛を円板の端に付け，レンズで昖 大して見る構成である.

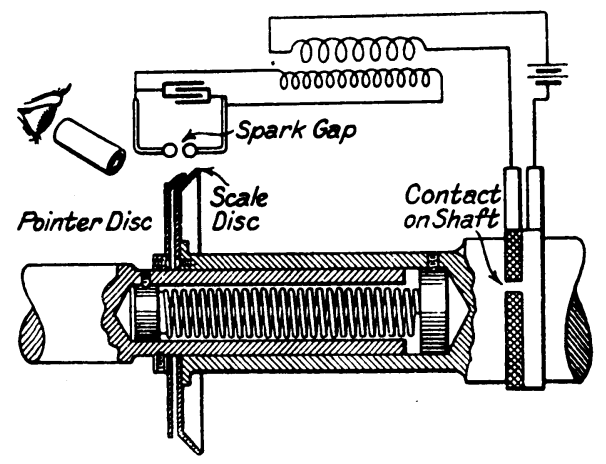

図28 Kinter 式ねじり動力計

(20) Görges-Weidig 式ねじり動力計 ${ }^{(43)}$

図29のよ5に軸表面上の 2 点に 2 枚の反射鏡を張り 光源より光を反射させて光像の移動を望遠鏡で観測し てねじり角を知る.

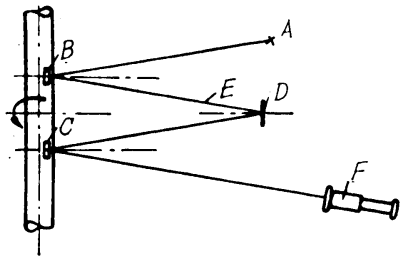

図29 Görges-Weidig 式ねじり動力計

(21) Vieweg-Wetthauer 式ねじり動力計 ${ }^{(44) \sim(48)}$

(a) 図30のように 2 個の直角プリズムを張り，それ を通して目盛板を望遠鏡で観測する． 3 角プリズムは 光線を直角に曲げにくいので 5 角プリズムに変えるこ とを考案した.

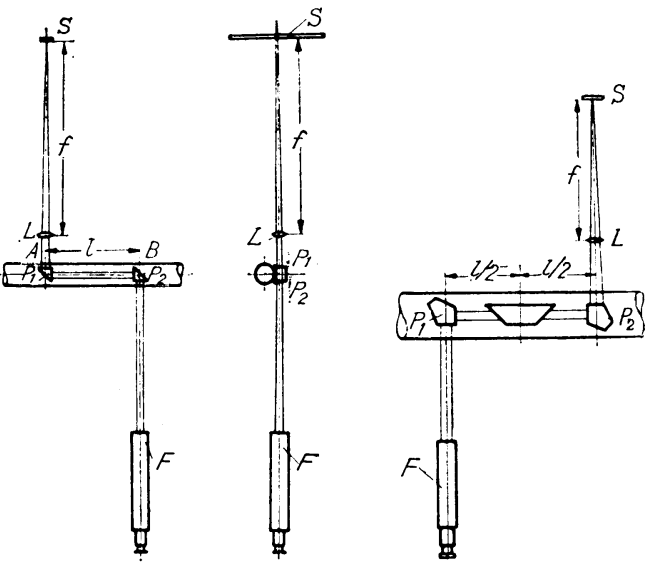

図30 Vieweg-Wetthauer 式ねじり動力計（a）

(b) 図31のようにスプリングによりねじり角を拡大 してプリズム閒隔を縮小した

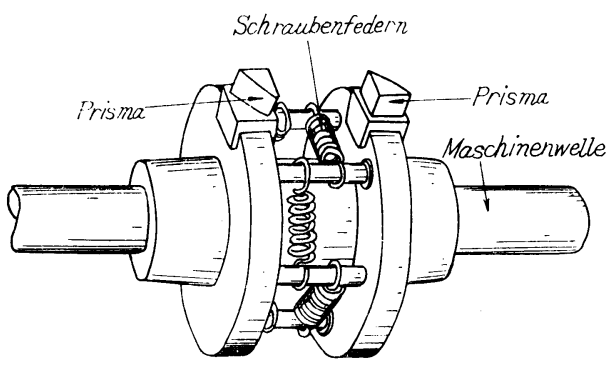

図31 Vieweg-Wetthauer 式ねじり動力計 (b)

(c) 14(b)を改良したもので,図32のように望遠鏡を使 用して中間軸のねじり角の目盛をさらに詳しく読む. スリットの幅を狭くできるから読みは正確となる。し かし光量が減るから読みにくくなる.

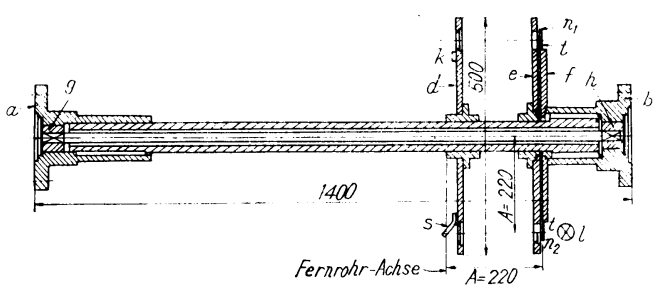

脳32 Vicweg-Wetthauer 式ねじり動力榊 (c) (22）Bauersfeld 式ねじり動力刷 (45)

21 と同様 2 個のプリズムの位置によりねじり角を知 る. 図33のようにプリズムの間隔を縮小するためスリ ーブを付け，望遠鏡と目盛板を同一の台上に置いて調 整を容易にしている.

（23）末広式ねじり動力計(49) (51)

図34のようにスリーブ上軸に垂直に腕を取付け，ス リーブのないほらの腕の先に目盛と標線を付けたすり ガラスがある，Mは平面鏡， m は凹面鏡で，望遠鏡で 


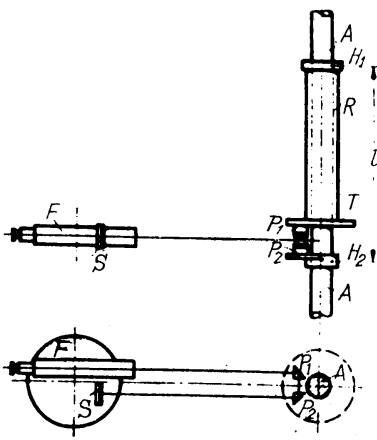

図33 Bauersfeld 式ねじり 動力棓

観測するとき軸心に S の像を結ぶ ように調整する，目盛像は平面鏡 により，標線は凹面鏡により，別 々に反射されて望遠鏡に人るから， 目盛と標線のずれを観測すればね じり角が測定される. 1 回転 1 回 の観測であるから瞬時值が見える.

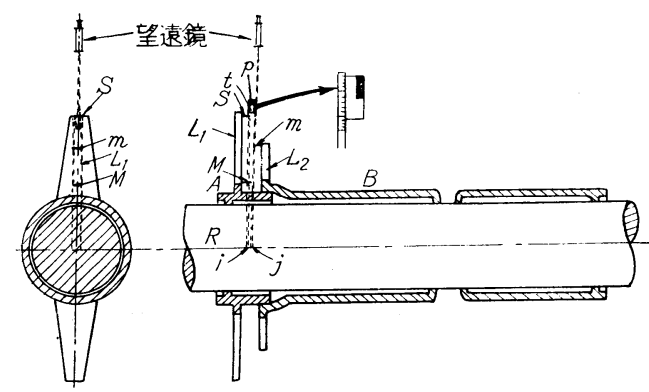

図34末広式ねじり動力棓

（24）Frahm 式ねじり動力計 (52) (55)

図35のように機械的に鏡の角度を変え，スリーブ固 定端の光源からの光の投射を受け，反射し，光源と同 じ場所に取付けた写真フィルムに撮影して記録する. フィルムの取替えには軸を止めるので試運転に使用さ れる。

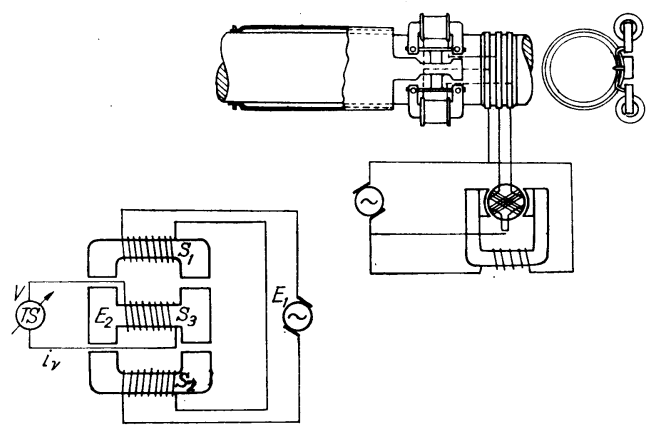

図36 Keinath 式ねじり動力計
（25）Keinath 式ねじり動力計(56)

図 36 のよ5に 1 次巻線のある鉄心 2 個を並べ, その 間に 2 次巻線のある中央鉄心を置き，中正の位置のと き, 1 次巻線 2 個を 2 次巻線に対し磁束を打消し, 電 圧を誘導しないようにすれば，2 次誘導電圧は中央鉄 心の偏位量に比例する. 自己インダクタンスを変化す る場合はスリーブの端に中央鉄心を付け，1次巻線の 鉄心はそれに対応して軸に固定する.

(26）Batson-Hyde 式ねじり動力計 ${ }^{(3)(7)}$

図37において回転軸 $\mathrm{A}$ はスリーブ E で囲まれ，Eは $\mathrm{F}$ に固定する. F 中のコイルスプリングの外側は F に 内側の端はAに固定している. 円板 B はら線状にロー ラCの上を動くから， B の位置を示す目盛は $\mathrm{A}$ のねじ り角を示す.

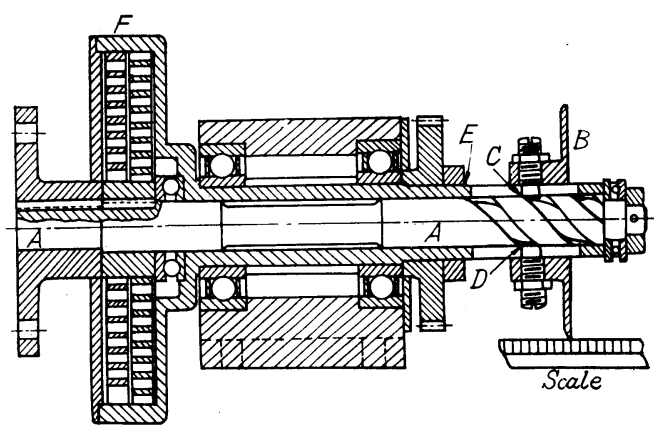

図37 Batson-Hyde 式ねじり動力訶

（27）Elässer 式ねじり動力計(57)

図38のように細い中間軸で結び，スリーブの端と対 


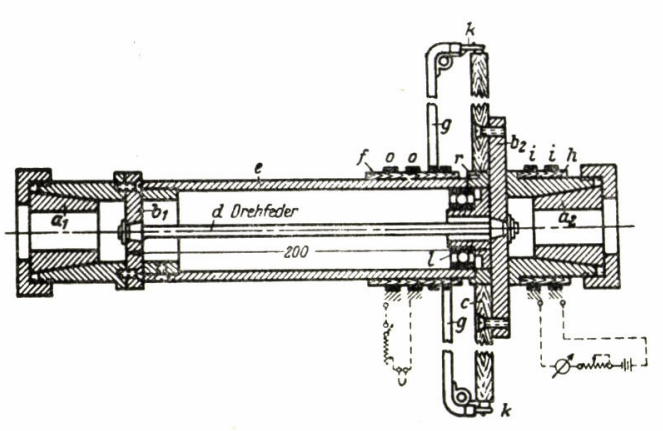

図38 Elässer 式ねじり動力計

忘した部分に円板を取付けそのうえに抵抗体，ブラシ が電橋を作るように取付けられる。

(28）Krupp 式柿じり動力計 (6)

図39のように 2 枚の円板の間に弾性体を入れ, 軸を 短くした，27と同一原理である. 変動の少ない電動機 の能率測定に使用される。

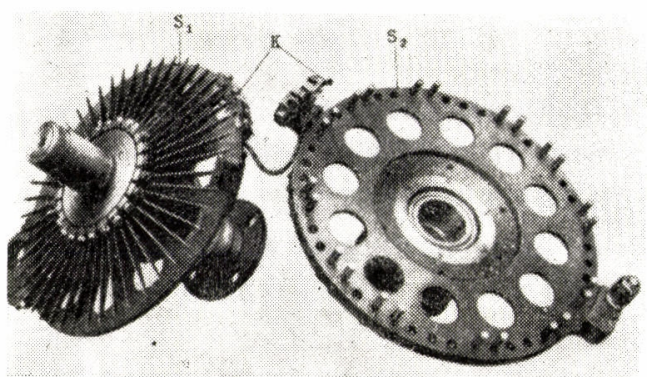

図39-1 Krupp 式叔じり動力計（a）

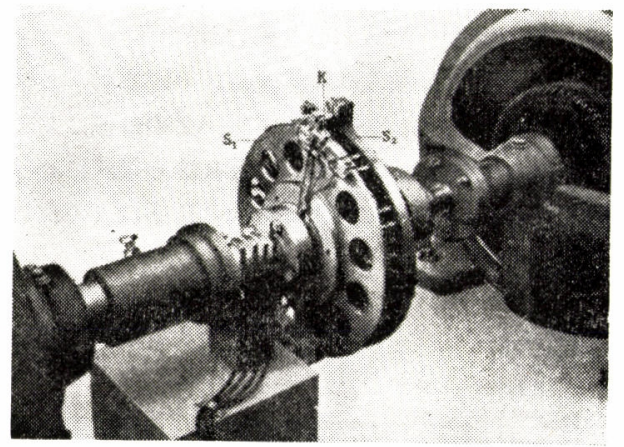

図39-2 Krupp 式䄈じり動力計 (b)

(29) Moullin 式叔じり動力計 ${ }^{(58) \sim(60)}$

25 と同様で図40のよらにスリーブの端に自己インダ クタンスの鉄心を取付け，間隙を扔いて鉄心を軸に固 定する。軸のたわみの影響を少なくするため, 軸のま わりに対称の位置にインダクタンス鉄心を置く.

(30) Klein 式ねじり動力計 ${ }^{(61)}$

図41において $\mathrm{f}$ は中間軸， $\mathrm{a}$ は中間軸で，cにより

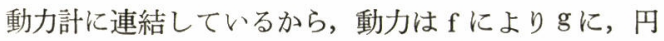
筒 $\mathrm{h}$ によりピンdに伝えられる. ねじり角は傘歯車

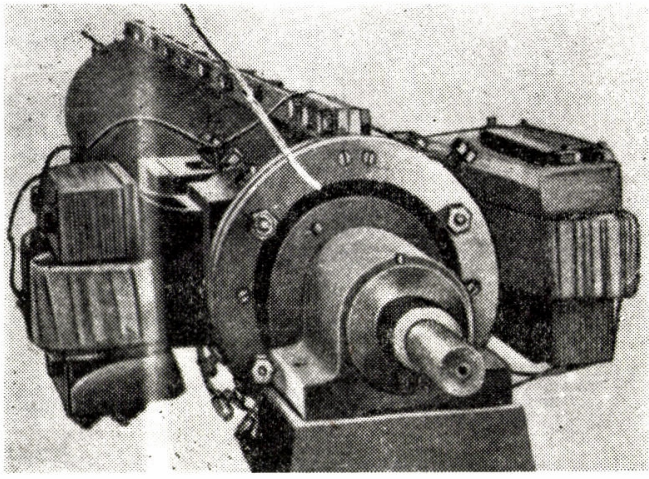

図40 Moullin 式叔じり動力計

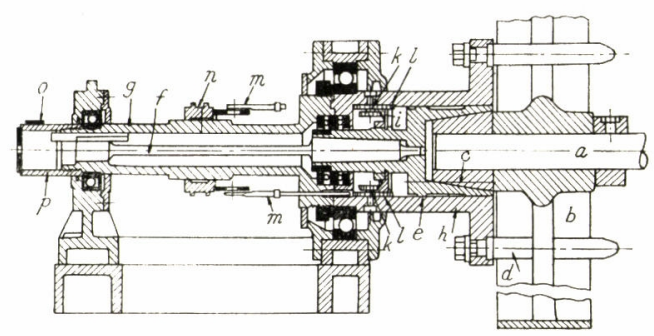

図41 Klein 式叔じり動力計

$\mathrm{i}, \mathrm{k}$ などの作用により棒 $\mathrm{m} \mathrm{m}$ の繸方向の運動に変え られる。

(31） Ford 式权じり動力計 (52) (65)

図42のように軸上，軸外の可変インダクタンスの 1 次回路, 2 次回路は直列に接続し，2 次回路は誘導電 圧が逆になるように接続して計器に入る. 電源は交流 または直流の断続を加える。軸上, 軸外の相互インダ クタンスが等しければ計器の指針は振れないようにマ イクロメーターを調節する.Mc-Nab Ford, Taylor Model Basin (Ford, Mark I) も同様である.
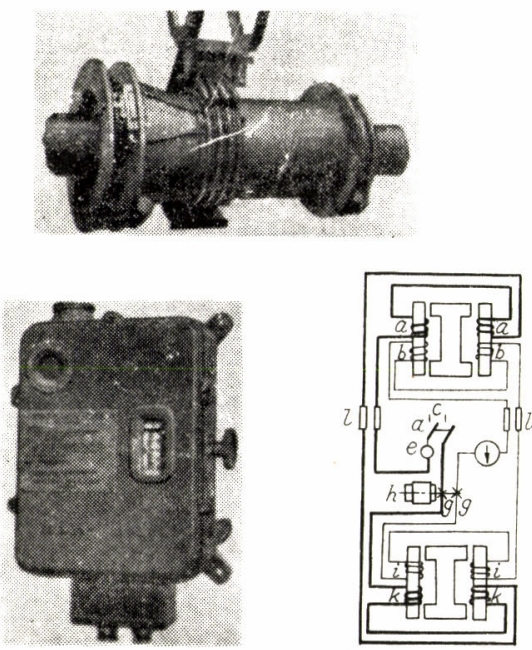

図42 Ford式祀じり動力計 
(32） Parker-Jackman 式ねじり動力計 ${ }^{(66)}$

反射鏡を回転させる機構が 24 と異なるだけで他は大 体同様で，反射光をフィルムに写す記録装置である. スリーブ円板式で宝石軸受上に支えられた鏡を回転す る.

(33) Hoppe-Maihak 式ねじり動力計 (67) (70)

軸上 2 個の腕を図43のように取付け，その先に鋼線 を軸のまわりに切線方向に張る. 鋼線を電磁石で振動 させ, 近くの巻線に電圧を誘導させ, スリップリング, ブラシにより受話器に伝える. 司令室には同じ鋼線の 装置があり，マイクロメーターで張力を調節し，音を 加減し，音を同じにしてねじり角を知る。

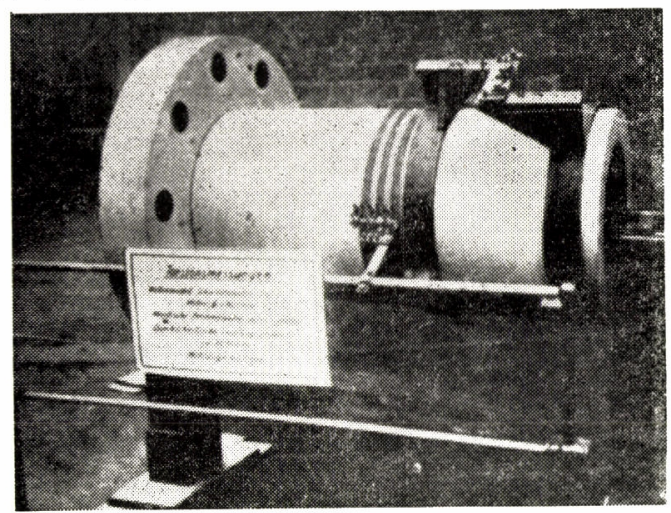

図43 Hoppe-Maihak 式㸚じり動力計

（34）小林式ねじり動力計 ${ }^{(71)}$

図44のように航空機のエンジンの軸馬力を測定する 目的で磁気ひずみ効果を利用した. 寸なわち, 電流を 通じた強磁性体をねじれば，軸方向に磁化される。こ の磁化の強さは軸と同心の 2 次コイルの誘導電圧から 測定される.

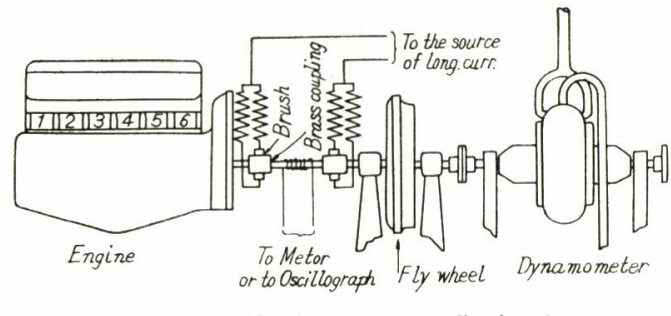

図44 小林式ねじり動力計

(35) Morin 式ねじり動力計 (7)

板スプリングで連結してスプリングのひずみを図示 する。図45において，Eは自由滑車，BはEにより動

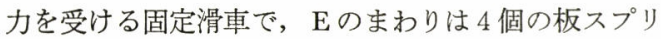
ングで軸に連結する，2本の鉛筆があり，一つは記録

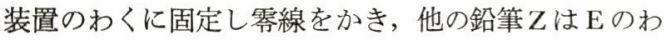
くに固定しスプリングの延びを記録する.

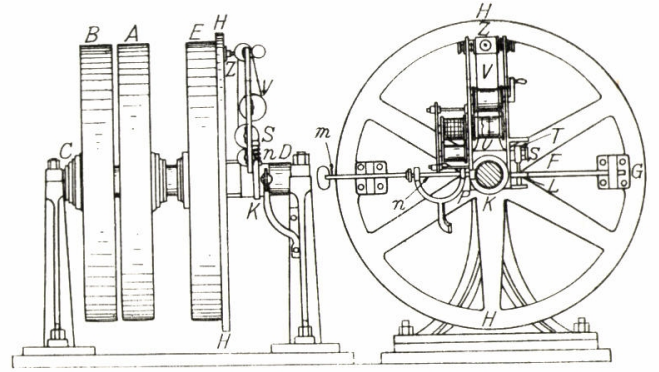

図45 Morin 式ねじり動力計

（36）金尾式ねじり動力計 (72)

細い中間軸によってねじり角を増大する，軸上 2 点 の歯車伝達により直流または交流発電機を運転し, そ の出力電力を直列にして電圧計に接続すれば，その值 は動力に比例する.

(37) Gramberg 式ねじり動力計·(35'(73)

35 の変形で図46のように軸を切りスプリングで連結 する. 軸の両端の 2 個の円板を接近させて溝 $\mathrm{S}_{1}, \mathrm{~S}_{2}$ の交さ点を見てねじり角を観測する，回転により交差 点は半径方向に動く，明滅すると見にくいので一定負 荷に限る。

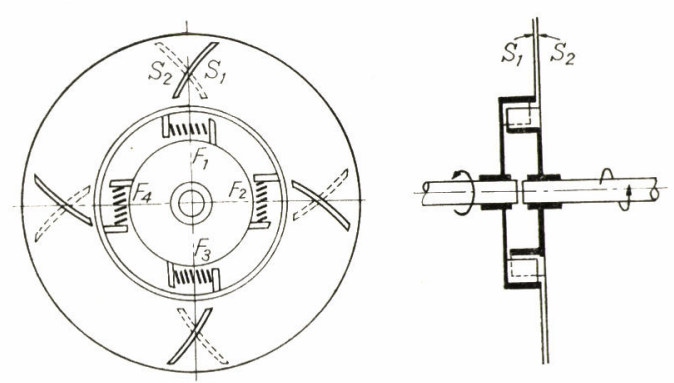

図46 Gramberg 式ねじり動力計

（38）研野式ねじり動力計 (74) (77)

光学的記録装置で，軸上の 2 点に環を固定し，一力 に叮面鏡を固定し，他方に光源と写真機を固定し，こ れらは軸とともに回転する。像は細陌, 拡大レンズ, ポロプリズム，円筒レンズなどよりなる光学系により 軸の回転力に比例する位置に像を結ぶ.

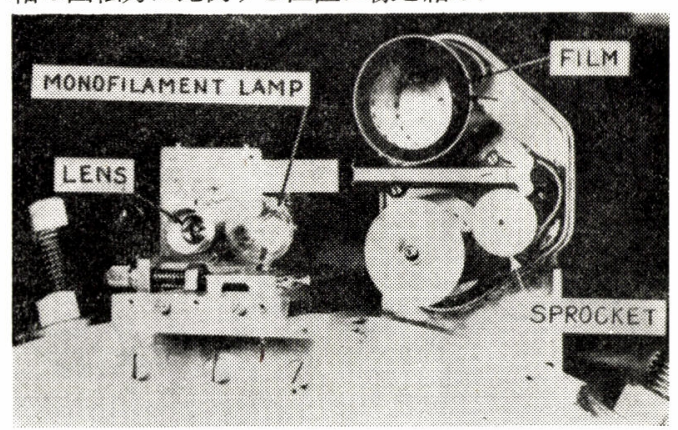

図47研野式称じり動力計 
図47は一例で，このほかにも各種のねじり計を考案 試作した．また，これを使用して測定する場合の基準 となる中間軸のせん断弾性係数を実測し， $8.31 \times 10^{5}$ $/ \mathrm{cm}^{2}$ がもっとも適当であることを提案した。

(39）松本式ねじり動力計(78 (79)

相互インダクタンスの変化を利用する方式で, 図 48 , 図49に示すよ5に，1 次巻線による磁束のある空隙中 に 2 次巻線を移動させ誘導電圧を変える，この際誘導 電圧と巻線移動を比例するよらにする，構造はスリ一 ブの端に相対して 2 個この装置を付け， 1 次巻線で直 列にする. 可動コイル形電圧計で㸚じり動力を知る. 三菱長崎の長船式はこれを改良したものである。
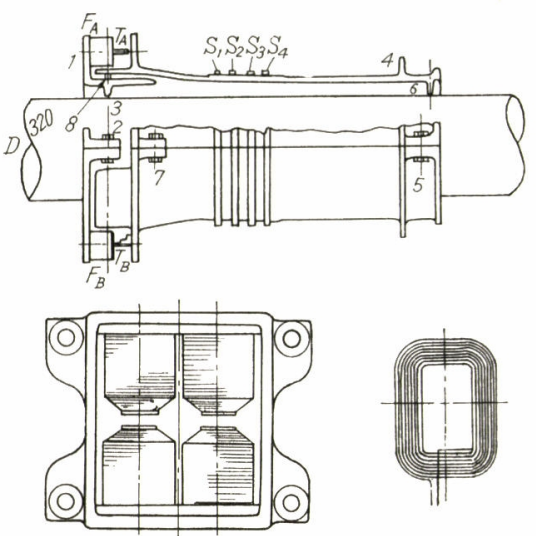

図48 松本式ねじり動力棓

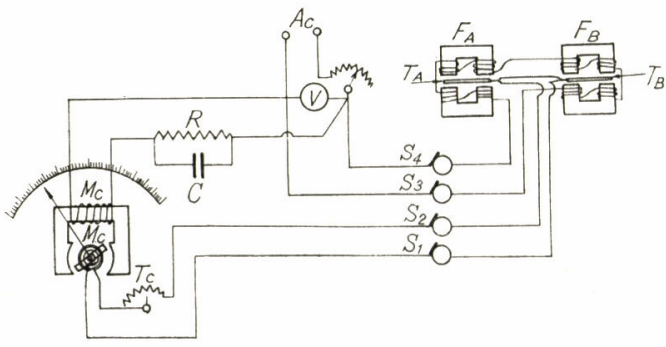

図49 松本式ねじり動力計（回路図）

（40）浜部式ねじり動力計 ${ }^{(80)}$

動力を直読するため直流または交流発電機を軸に直 結し, 発生電圧を回転速度に比例させ, その電圧を読 む. 図50のよらに細い中間軸を使用し，両側からスリ
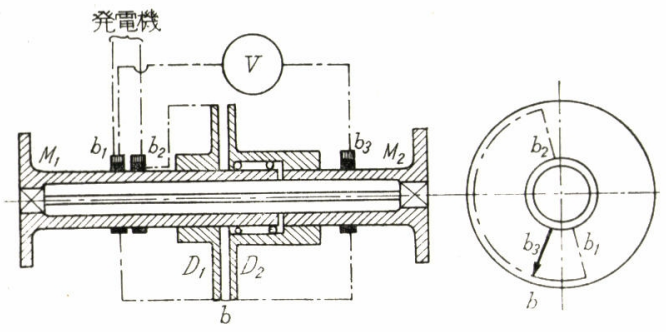

図50 浜部式水じり動力計
ーブを出し，中央で円板を向合わせる．27と同様，抵 抗変化式で円板の周囲に抵抗線を張付けブラシをあて る. 測定電圧は伝達動力に比例する。

(41) Müller 式ねじり動力計(81)

図51において軸上の 2 点に目盛円板 B，C を取付け ストロボスコープ式に軸外の標点 D， Eに対する目盛 を読む. 照明にはネオン管 F， Gを用い，感応コイル の 1 次巻線の断続によって明滅させる，1 次回路の断 続は軸上の接点で行なう。Hは感応コイル，I は放電 間隙，Nはコンデンサである.

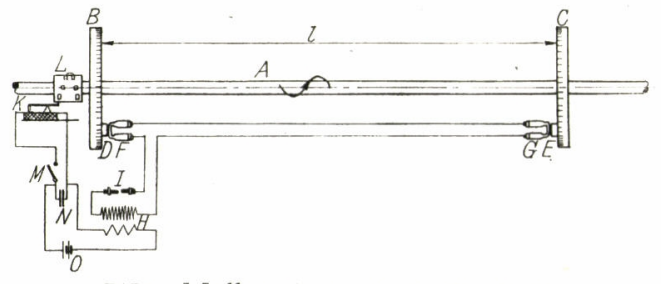

図51 Müller 式 ね

(42) 瀬藤式ねじり動力計 (82)(83)

誘導子形交流発電機の原理を利用した方式で, 四52 のように周辺に 120 個の円孔または凸極のある円板を 軸上の 2 点に取付けて誘導子とし, これに対して直流 励磁の鉄心に巻いた発電子巻線を床面に固定する。 二 つの誘導電圧を直列に結び電圧計によりねじり動力を 直読する。

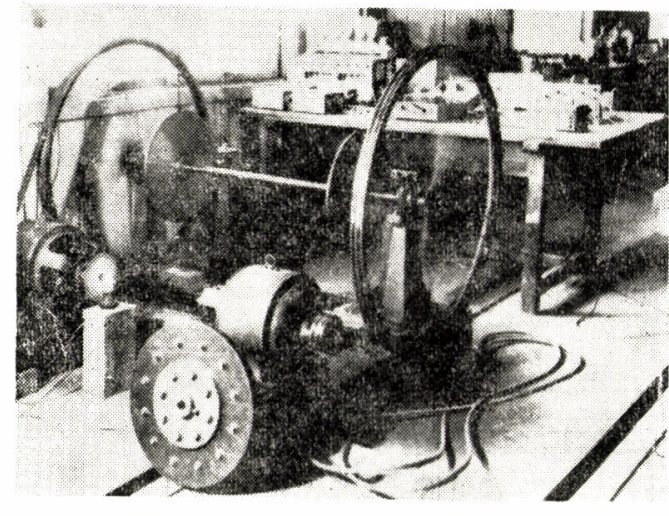

四52 瀬藤式叔じり動力計

(43) 近藤式放じり動力計 ${ }^{\prime 811}$

図53のようにねじり角による静電容量の変化を利用 寸る方式で, かご形誘導電動機の回転力, 速度特性測 定に使用した。細い䄈じり軸により礼じり角を増大し それに比例して電極の相対する面積が変化する。

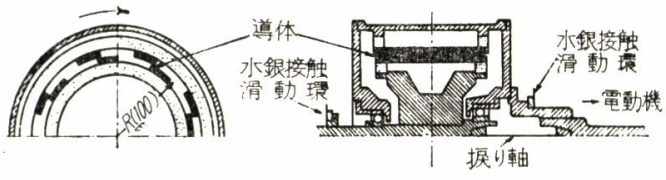

図53近藤式衫じり動力計 
(44) White-Fox 式ねじり動力計 ${ }^{(85)}$

(a) 回路の機械的断続によって流れる電流で電力計 積算電力計を働かせる方式で 12 と同様である。ねじり 角測定間隔を大きくして軸に取付けた歯車により回転 速度およびねじり角を増大，接点断続機を働かせる。 電源は軸と鎖連結した発電機で回転速度に比例した電 圧を使用している.

（b）軸に取付けた歯車によって脇軸に回転を后え, 差動歯車により積算動力を記録する機械的装置であ る.機構は図54のように 2 標点において歯車鎖の維命 せにより脇軸に同方向の回転, 逆方向の回転を与え, その端の回転を差動歯車により垂直軸に伝える。重 直軸は歯車の組合せにより脇軸より回転速度を少なく して, その先の球表面の屋根を軸のまわりに回転させ る. 主軸にねじれがないときは, 垂直軸が垂直になる ように調節して置くと，ねじりにより脇軸の位相がず れて脇軸のまわりにねじり角に比例した角度に傾いて 回転する。

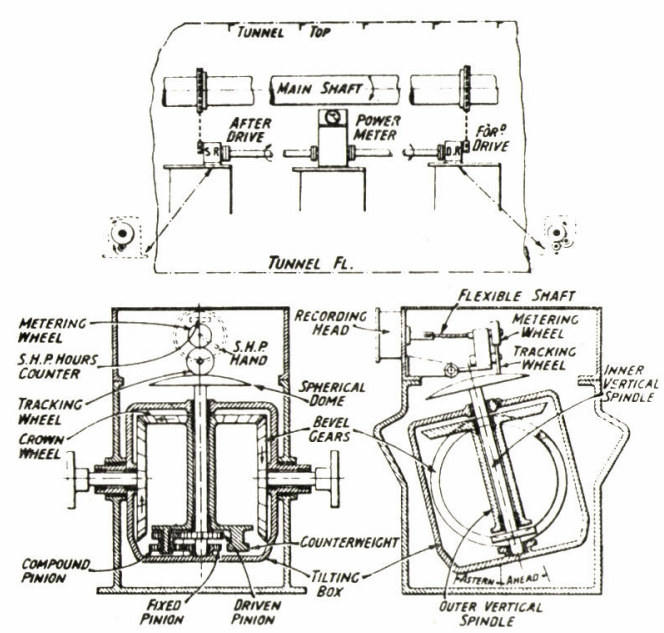

四54 White-Fox 式ねじり動力計（b)

(45) Siemens-Halske 式㸚じり動力計 ${ }^{(86)}$

相対する板電極の距離の変化により容量が変化する ことを利用し，曲げモーメントの影響を除くため電極 2 組を図55のように $180^{\circ}$ 隔てて取付け, 容量を並列に

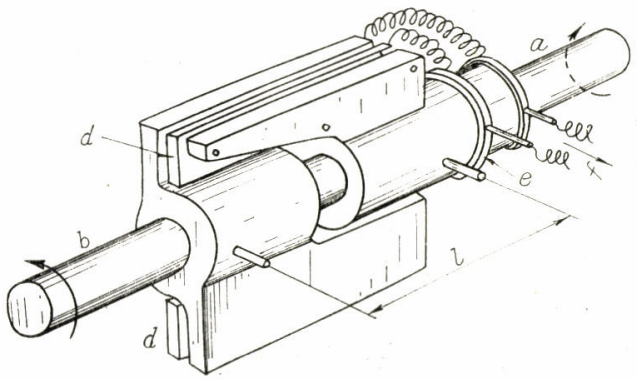

図55 Siemens-Halske 式ねじり動力計
接続する．測定には容量ブリッジを組み，5,000 サイ クル電源を使用し, 急激な変動記録に適する。 $\mathrm{a}$ 負荷 側, b 駆動側, 1 標点距離, $f$ 容量変化測定器への接続.

(46) G E 式衫じり動力計 ${ }^{(87) ~(92)}$

(a) 図56のように誘導子形交流発電機を使用し，42 (a)と同様である. 励磁には永久磁石を使用し, 軸と発 電機との間は軸受で固定し, 発電子は床に対しある程 度の弾性をもっている，船舶の軸馬力および積算軸叟 力が常時測定できるようになっている.

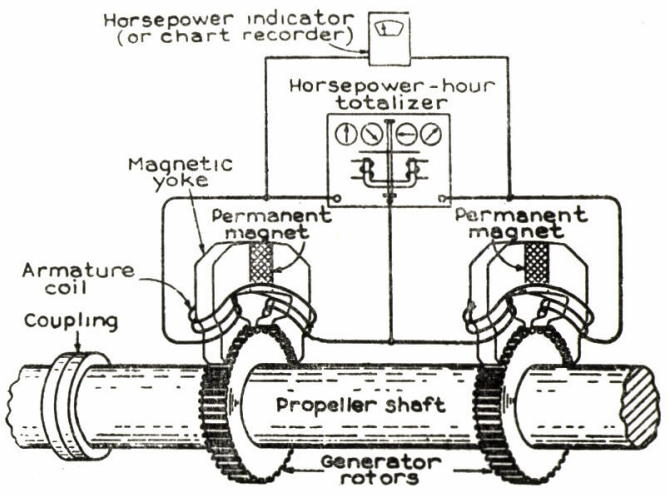

四56 G E 式䄈じり動力計 (a)

(b) 25 と同様自己インダクタンスの変化を利用する 方式である. 図57のように中央鉄心の偏位に比例する 電圧と， 3 相交流発電機による軸の回転速度に比例す る電圧との積により軸馬力を常時直示し, さらに積算 軸馬力を直示することができる．この当時までに考案

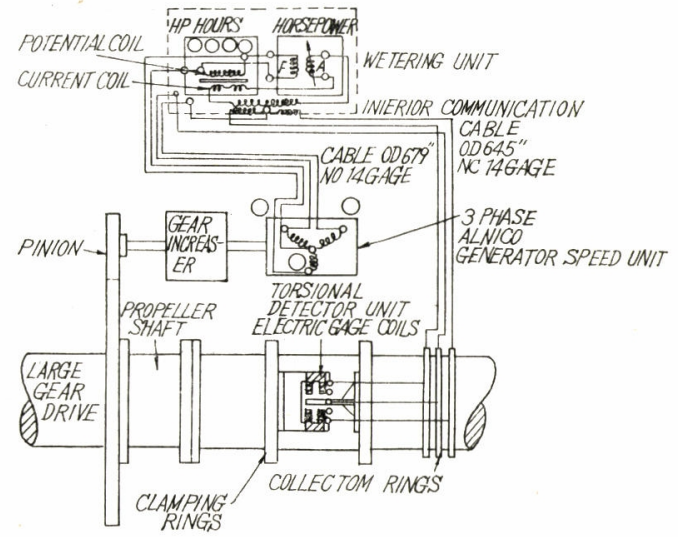

図57 GE 式秝じり動力計（b）(説明図）

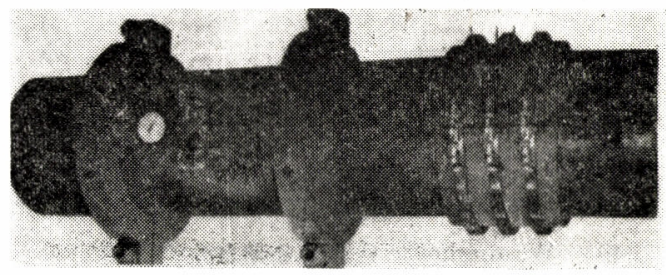

図58 $\mathrm{GE}$ 式ねじり動力計 (b)（外観） 
されたもので最も優秀な装置である，図58はその外観 である。最近は ASEAの Ring Torductorを利用し ている.

（47）海老原式ねじり動力計 ${ }^{(93)}$

水晶の圧電気を検出する方法で, 図59のように水晶 の板を軸内に入れ，ねじり圧力により発生する電圧を 真空管増幅器により増幅する. 軸から電圧を取出すと き, 軸のまわりに円筒形電極を置き, 静電容量により 測定する. したがって, 軸に接触する部分はない。曲 げモーメント, 軸推力の影響を受けない特長を有し, また急激な回転力の変動を測定するのに適する.
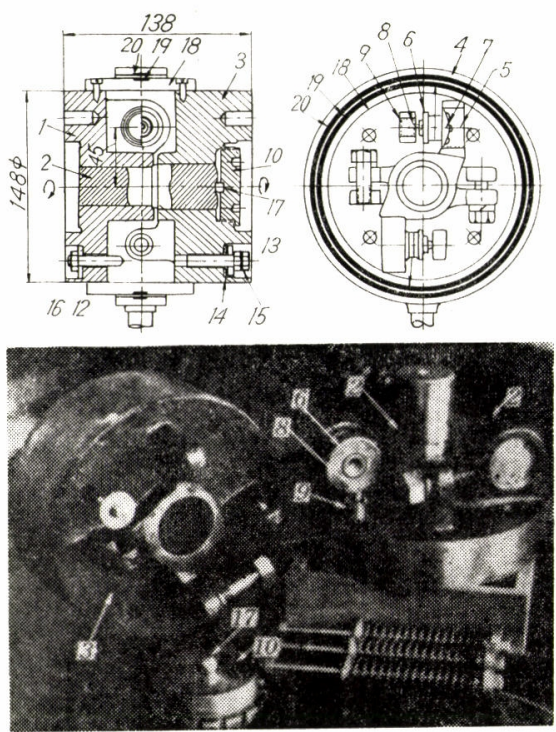

四59 海老原式叔じり動力計

(48) Naval Research Laboratory 式 $、$ じり動力 iेt (94) (97)

軸トルク, 出力, 回転速度の瞬時值を測定する出力 トルク計として米海軍研究所によって開発された. ホ プキンソントーションメーター式スリーブのさきに図 60 のよ5な可動電極のある測微真空管を取付け, 内部 抵抗の変化をブリッジにより検出する. すなわち 2 極 管の電極間距離を陽極に取付けた腕の移動により変化 させる. 電極構造により偏位と電流が比例する.

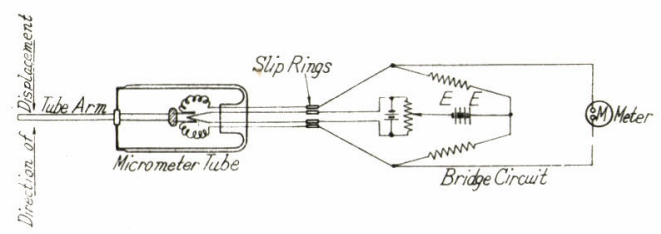

図60 NRL 式 小方り動力計

(49) Westinghouse 式ねじり動力計(97) (104)

抵抗および静電容量によるスレンゲージが開発され
エンジンモニタリングに使用されるようになった。わ が国にも半導体を使用したものなど数多くある.

（50）日立造船式礼じり動力計 ${ }^{(105)(106)}$

磁気ひずみ式軸馬力計で，中閒軸に装着した二つの 筒の相対変位を磁気ひずみ管のねじりに変え，このね じりを軸方向に交番磁化した強磁性体の管の㸚じり磁 気ひずみ効果を利用して電気的に計測する。図61の 1 次コイルの交流を一定に保ち，磁界を一定にすれば， 2 次コイルの電流により, 中間軸の回転力を求められ る. その後差動変圧器形を採用した.
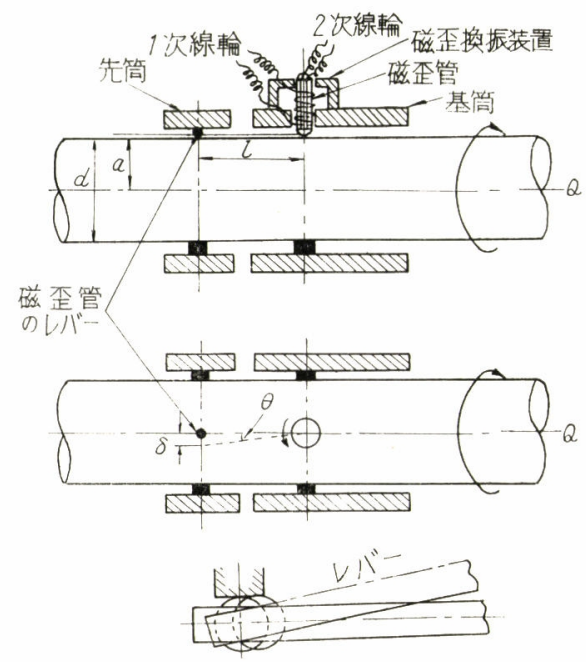

図61 日立造船式衫じり動力偐

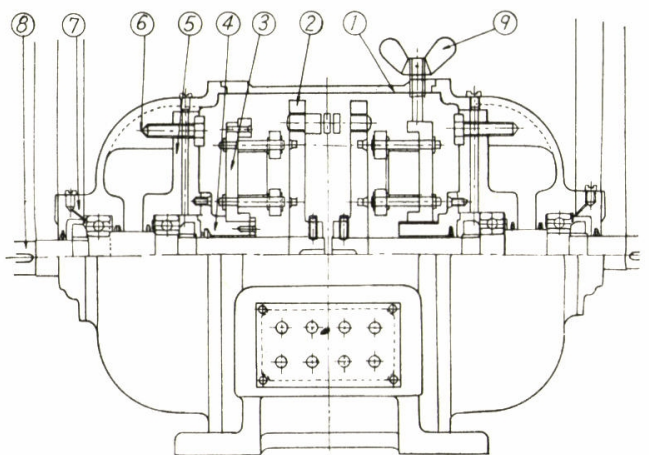

図62 伊什式政じり動力計 (a)

（51）伊丹式 ねじり動力計 (107)(108)

(a) 図62のよ うな無接触式に よる軸馬力計を 試作した。 円板 2 にボルトを立 
て軸のねじれをスプリングののびに変えている. 円板 は同時に誘導子の役目をしている. 㸚じりは電圧の位 相差角となり, 速度は電圧の大きさとなるので, 軸馬 力を電圧計で測定できる.

(b) 本誌発表の電気式舶用積算軸馬力計を考案した.

（52）三菱重工業神戸造船所式ねじり動力計 ${ }^{(109)(110)}$

(a) サーチコイルを軸に対称の位置に 2 組取付け, ねじりに相当する移動がサーチコイルの可動鉄心に与 えられ, 空隙の変化による誘導電圧により㸚じり動力 を測定する.

（b）本誌に発表の無接触方式による舶用軸馬力計を 考案した.

（53）三菱重工長崎造船所式ねじり動力計(111)

スリーブと差動可変インダクタンスによる相対角変 位を電気式測微計により自記またはメーターにより読 みとる方法である。

（54） Muirhead 式ねじり動力計(112)

二つの磁気検出器における検出電圧の時間差のパル スがトルクに比例し, 回転速度を掛け, 計数器で軸馬 力を積算する.

(55） ASEA 式ねじり動力計 ${ }^{(113)}$

スリップリングのないトルク変換器として新しいリ ングトルダクターとして発表された． GE の軸馬力計 も最近はこれを使用している.

（56）三井造船式秝じり動力計 (114)

誘導式ピックアップによりねじりを測定する方法で 誘導子形交流発電機の原理による．無接触方式により 軸馬力が求められる. 本学会で講演発表されている.

\section{2 ねじり動力計の分類}

\subsection{1 構造上の分類}

(A) 軸のねじり角を直接測定する構造

(a) 測定点間隔を直接測定する構造

(1) 軸表面で直接行なうもの $20 ， 21 ， 38 ， 49$

(2) 円板，歯車などを付けたもの $3,5,6$, $12,17,18,41,42,42,45,46$

(b) スリーブ,腕を延ばし測定点間隔を縮小した構造

（1）スリーブの端で直接行ならもの $18 ， 50$, $51,52,53,54,56$

(2) スリーブの端に円板などを取付けたもの

$5,7,8,9,10,14,22,23,24,25$, $29,31,32,39,48$

(3) スリーブの代りに軸の内部に円筒があって測 定点間隔を縮小したもの $11 ， 16 ４$

（4）腕を延ばしたもの $18 ， 33 ， 46$

（B） 軸を切断して，その間をスプリングをたは中間軸 で連結してねじり角を増大した構造 (a) 細い軸で連結し，スリーブを付けたもの $2,14,21,26,27,28,30,36,40,43$

(b) スプリングで連結したもの $\quad 1 ， 4,13,15$ 19, 21，35，37，42，51

(C) ねじり角の代りに応力を使う構造 34,47

\subsection{2 測定上の分類}

(A) 機械的測定法

（a）てこ，スプリングを利用してねじり角を増大し たもの $1,4,5,16,26,35$

（b）鎖，歯車を利用してねじり角を脇軸に取出した もの 44

(c) 歯車，円板，綱を利用したもの 9,18

(B) 光学的測定法

（a）反射鏡，プリズムによる像の変化を読むもの $7,20,21,22,23,38$

(b) 軸上の目盛偏位をストロボで読むもの $9,14,18,19,23,41$

(c) 二つのスリットの相互変位により光の進路を変 えるか像の形を変えるもの $5,10,11,30,37$

(d) スリットを通して目盛偏位をストロボスコープ 式に読むもの 14,21

(e) 光像記録装置のあるもの $24,32,38$

(f) 機械光学的 $7,9,24,32$

(C) 電気的測定法

(a) ドラムに印をつけその位置を測定するもの 5

(b) 接点の断続によって零点を求めるもの $3,14,17,18$

(c) 接点の断続によって流れる電流の大きさを読む もの $4,12,44$

（d）鋼線張力を振動数に変え受話器で聞くもの 33

(e) 特殊の発電機の誘動電圧を受話器で聞き零点を 求めるもの 6,8

(f) 誘導子形交流発電機の原理を利用するもの $13 ， 18 ， 42 ， 46,51,52 ， 54 ， 56$

(g) 直流発電機の電圧を読むもの $13,36,40$

(h) 交流発電機の電圧を読むもの $15,39,40$

(i) 抵抗の変化, 電圧降下を読むもの（す心゙り抵抗 器式) $9,27,28,40,48$

(j) スレトンレゲージによるもの 49

(k) 空隙の変化による電磁誘導変換方式 $(\mathrm{L})$

$25,29,31,39,45,46,50,51,52,53$

（1）静電容量の変化を利用するもの(C) 43,45

(m) 圧電気を利用するもの 47

(n) 磁気ひずみを利用するもの 34,50

\section{3 ねじり動力計の現状と将来の動向}

トルクやスラストの測定については Towns ${ }^{(115),}$ 
Cook $^{(97)}$ ，Morrison ${ }^{(104)}$ の諸氏により簡単な展望が行 なわれているが，諸外国およびわが国のねじり動力計 の現状はどのようであろうか.

\subsection{1 トルク，軸馬力を測定する理由}

ねじり動力計は今まで数多く作られているが，実際 はどのようなことに使われているか.

(1) 海上公式試運転用

(a) 船の契約速度を出すのに必要な軸馬力を正確に 測定するため

(b) エンジンの燃料消費量を正確に求めるため

(c) 将来の設計の基礎として実船と模型船との相似 性について正確な資料を求めるため

(2) 経済運転用

(a) エンジンの経済運転上の燃料消費を絶えず確認 するため

（d）安全運転の期間あるいは経済運転の期間を決定 するための運転性能の確認

(3) 将来の開発用

（a）ねじり振動や軸振動特性を決定する計測用

(b) 急停止あるいは運転中の制御用

(c) データロガー用, 出カフィードバック用

以上はその二，三に過ぎないが，どのような目的に 使うかにより, 原理, 構造, 計装などが考慮されなけ ればならない.たとえば，公試用ならばスリップリン グの問題はあまり心配しなくてもよいが，長期間運転 するものでは当然細心の注意を要する.

\subsection{2 使用状況}

英国は British Research Association によればつぎ のものが使用されている.

(1) A.E.I. Electric Torsionmeter (Siemens-Ford)

(2) Maihak Torsionmeter

(3) Electric Resistance Strain Gauge

(4) Elenik-Götaverken Power Log

(5) Sfindex-Aerotron Torque Meter

(6) Photo Stress Torque Meter

(7) ASEA Ring Torductor

(8) David Taylor Mode Basin Torsionmeter

(9) Muirhead Integrating Power Meter

(10) Hans Hoppe Torsionmeter

米国は Society of Naval Architects and Marine Engineers によればつぎのものが使用されている.

(1) Mc Nab-Ford Torsionmeter

(2) David Taylor Mode Basin Torsionmeter

(3) General Electric Shaft Horsepower Meter

(4) Gary-Cummings Torsionmeter

(5) Hopkinson-Thring Torsionmeter
(6) Frahm Torsionmeter

(7) Baldwin-Southwark Torsionmeter

(8) Maihak Torsionmeter

(9) Smith Erickson Torsionmeter

(10) Naval Research Laboratory Torsionmeter 日本では現在つぎのものが使用されている.

(1) ホプキンソントーションメーター（東京計器で 製造, タービン船専用, 常用, 光学式)

(2) 研野式ねじれ計（試運転時, 光学記録式)

(3) Maikak（試運転時）

(4) Siemens-Ford (常用)

（5）電気式舶用積算軸馬力計（東芝で製造，常用）

（6）日立造船軸馬力計（常用）

（7）三菱重工神戸造船所軸馬力計（常用）

（8）三井造船玉野造船所軸馬力計（常用）

（9）共和電業軸馬力計 (常用)

(10) ストレンゲージトルク計（試運転用）

以上のほかに二，三実用されているものがあるが， 使用目的により十分注意して選択し，常に整備する必 要がある. データロガーとしてのねじり動力計は信頼 性の点でもあまり複雑な機構でないことが望ましい. ASEA の Ring Torductor は将来さらに進歩するよう に考えられる.

\section{4.あとがき}

動力測定の現状と将来の動向について概要を述べた が，回転動力の測定には軸のせん断弾性係数が重要な 役割を果たしている. 将来動力測定に関する研究ある いは軸のせん断弾性係数に関する研究がいっそう活発 に行なわれることを期待する.

\section{文献}

(1) P. Nettmann: Der Torsionsindikator 1, 2, 3 (191213)

(2) E.A. Griffiths: Engineering Instruments and Meters (1920)

(3) R.G. Batson and J.H. Hyde: Mechanical Testing 2 (1922)

(4) A. Gramberg: Techniche Messungen 1 (1922)

(5) C.V. Drysdale and A.C. Jolley: Electrical Measuring Instruments 2 (1924)

(6) H. Steuding: Messung Mechanischer Schwingungen (1928)

(7) H. Diederiches and W.C. Andrae: Experimental Mechanical Engineering 1 (1930)

(8) A.W. Judge: The Testing of High Speed Internal Combustion Engines (1932)

(9) The Mechanical Efficiency of Marine Engines. The Engineer, Vol. 106, p. 505, 506 (1908)

(10) P. Nettmann: Uber Torsionsindikatoren. Die Turbine, Vol. 9, p. 319, 337, 355 (1912-13)

(11) P.A. Borden: Electrical Measurement of Physical Values. T.A.I.E.E., Vol. 44, p. 247 (1925)

(12) V.W.H. Towns: The Measurement of Torque and Thrust in Ships. The Engineer, Vol. 160, p. 523 (1935) 
(13) Fischinger: Arbeitsmesser. Zeitschrift für Elektrochemie und angewandte physikalis Chemie, 537 (1891)

(14) F.J. Jervis-Smith: A New Method of Measuring the Tortional Angle of a Rotating Shaft or Spiral Spring. Philosophical Magazine and Journal of Science, Vol. 45, p. 183 (1898)

(15) H. Föttinger : Effektive Maschinenleistung und effektives Drehmoment und deren experimentelle Bestimmung (mit besonderer Berucksichtigung grosser Schiffsmachinen) Dissert. T. H. München (1904): F. V. d. I., Vol. 25 (1905): Jahrbuch der Schiffhautechnischen Gesellschaft, Vol. 4, p. 441 (1903)

(16) H. Föttinger : Die neuesten Kostruktionen des Torsionsindikators und deren Versuchsergebnisse. Jahrbuch der Schiffbauteshnischen Gesellschaft, Vol. 6, p. 135 (1905)

(17) Denny and Johnson's Torsion-Meter. Engineering, Vol. 79, p. 440 (1905): Journal of the American Society of Naval Engineers, Vol. 19, p. 406 (1907)

(18) Torsion-Meter. Engineering, Vol. 19, p. 65 (1911)

(19) A. Denny : Torsionmeters as applied to the Measurement of Power in Turbine and Reciprocating Engines. Transactions of the Institution of Naval Architects, Vol. 49, p.121 (1907)

(20) The Mechanical Efficiency of Marine Engines 1, 2. 3, The Engineer 1, Vol. 106, p. 505 (1908): 2, Vol. 106, p. 614 (1908): 3, Vol. 107, p. 77 (1909)

(21) H. Gibson : Torsionmeters in Marine Work. Transactions of North-East Coast Institution of Engineers and Shipbuilders, Vol. 24, p. 151 (1907-8)

(22) Hopkinson and Thring : A New Torsionmeter. Engineering, Vol. 83, p. 768 (1907): Z. d. V. d. I., 1044 (1907)

(23) B. Hopkinson: The Measurement of Shaft Horsepower. Engineering, Vol. 89, p. 429 (1910)

(24) B. Hopkinson : Notes on the Measurement of Shaft Horsepower. Transactions of the Institution of Naval Architects, Vol. 52, p. 184 (1910)

(25) American Patent, No. 888371, Mav 19 (1908)

(26) F. Edgecombe: Torsion-Meters. The Engineer, Vol. 106, p. 558 (1908)

(27) F. Edgecombe : Some Investigations with a New Form of Torsionmeter. The Engineer, Vol. 108. p. 471 (1909)

(28) Denny-Edgecombe Direct Vision Torsionmeter. Engineering, Vol. 119, p. 345 (1925)

(29) Torsionsindikator von Denny-Edgecombe. Zs. f. d. gesamte Turbinenwesen, Vol. 7, p. 28 (1910)

(30) Rundschau über Torsionsmesser. Z. d. V. d. I., Vol. 52 p. 679 (1908)

(31) H. Gibson: Torsion-Meters. Engineering, Vol. 85, p. 195 (1908)

(32) Quelques dynamometres récents. Revue de Mechanique, Vol. 26, p. 146, 259 (1910)

(33) H. Gibson : Les Torsionméters et leur application a la mesure de la puissance des turbines marines, d'aprés. Bulletin de la Société d'ecouragement pour Iindustrie nationale, Vol. 110, p. 282 (1908)

(34) Barr and Stroud : English Patent, No. 888371, May 19 (1908)

(35) A. Amsler : Some New Types of Dynamometres. Proceedings of the Institution of Mechanical Engineers, Vol. 3-4, p. 608 (1611)

(36) A. Amsler: Einige neue Transmissionskraftmesser. Z. d. V. d. I., Vol. 56, p. 1326 (1926) Z. d. V. d. I., Vol. 55, p. 1904 (1911): Power, Sept 5 (1911)

(37) E. Reichel: Versuche an einer Zentrifugalpumpe. Zs. f. d. gesamts Turbinenwesen, Vol. 5, p. 101
122 (1908)

(38) C. R. Moore: Electrical Apparatus for Measuring Power. Electrical World, Vol. 60, p. 449 (1912)

(39) H. Hohmes : The Gary-Cumming Torsionmeter Journal of the American Society of Naval Engineers, Vol. 24, p. 567 (1912): Z.d. V.d. I., Vol. 56, p. 1219 (1912)

(40) F. W. Sterling : Measuring Shaft Horsepower of Destroyers. Journal of the American Society of Naval Engineers, Vol. 20, p. 487 (1917)

(41) F. Lux: Ein neuer elektrischer Torsionsindikator. Jahrbuch der Schiffbautechnischen Gesellschaft, Vol. 13, p. 536 (1912)

(42) P. Nettmann : Untersuchung über den Einfluss einer Achsialbelastung auf dem Gleitmodul be Drehung. Die Turbine, Vol. 9, p. 119, 37 (1912-13)

(43) Görges and P. Weidig: Uber einen neuen Torsionsmesser zur Bestimmung des Drehmomentes rotierender Wellen. Elekrotechnische Zeitschrift, Vol. 34, p. 701, 739 (1913)

(44) V. Vieweg and A. Wetthauer: Die Bestimmung der Verdrehung umlaufender Wellen mittels Prismen oder Spiegel und inre Anwendung auf Torsionsdynamometer. Z.d. Vd. I., Vol. 58 , p. 615 (1914): Zs. f. Instr., Vol. 34, p. 137, 157 (1914)

(45) V. Vieweg: Die Messung des Drehmoments durch Tortionsdynamometer die mechanischer Kraftüberagung. Der Betrieb, Vol. 3, H. 13, 378 (1920-21)

(46) V. Vieweg: Uber Torsionsdynamometer. Deutsch Mechanikerzeitung, Vol. 73, p. 169 (1914)

(47) V. Vieweg : Tortionsdynamometer mit optischer Ablesevorrichtung. Z.d. V.d. I., Vol. 57, p. 1227 (1913): Zs. f. Instr. Vol. 34, p. 157 (1914)

(48) V. Vieweg: Eine optische Ablesevorrichtung für Torsionsdynamometer. Z.d. V.d. I., Vol. 58, p. 1016 (1914)

(49) K. Suehiro : On Torsionmeters. Journal of the Society of Naval Architects, Vol. 7, p. 1 (1909)

(50) Suehiro: A Torsion-Meter for Direct Observation. Journal of the Society of Naval Architects, Vol. 12. p. 67 (1913)

(51) K. Suehiro : A Transactions of the Institution of Naval Architects, Vol. 56, p. 166 (1914)

(52) H. Frahm: Ein Torsinsindikator mit Lichtbild zeichung ung seine Ergebnisse. Z.d. V.d. I., Vol. 62, p. 177 (1918)

(53) H. Frahm : Neue Untersuchungen über die dynamischen Vorgänge in den Wellenleitungen von Schiffsmaschinen mit besonderer Berücksichtigung der Resonanzschwingungen. F. V.d. I., 6 (1902): Z.d. V.d. I., Vol. 46, p. 797, 880 (1902)

(54) Torsion and Torsional Stresses in Propeller Shafts. Engineering, Vol. 75, p. 189 (1903)

(55) H. Frahm : Zahnradgetriebe für Turbinen und Motorschiffe der Werft Blohm und Voss. Jahrbuch der Schiffbautechnischen Gesellschaft, Vol. 25, p.81 (1924)

(56) Gg. Keinath: Ein neuer elekrischer Verdrehungsmesser. Dingl. polytechn. J. Vol. 335, p. 265 (1920)

(57) R. Elasser: Messen von Sehwingungen und Drehmomenten mittels des Oszillographen Zs. V.d. I. Vol. 68, p. 485 (1924)

(58) R.S. Wipple: Some New Recording Instruments. Journal of the Optical Society of America, Vol. 10, p. 445 (1925)

(59) Keinath: Einige neue Registrierungsinstrumente. Elektrotechnische Zeitschrift, Vol. 46, p. 1854 (1925)

(60) The Moullin Torsionmeter. Engineering, Vol. 117, p. 764 (1924): Electrician, Vol. 92, p. 631, (1924): Electrical Review, Vol. 94, p. 855 (1924): Mechan- 
ical Engineering, Vol. 46, p. 490 (1924)

(61) L. Klein: Torsion Dynamometer. V. D. I., Vol. 68, p. 830 (1924)

(62) The Ford Electric Torsion Meter. Engineering, Vol. 119, p. 190 (1923)

(63) Keinath : Elektrischer Torsionsmesser. Elektrotechnische Zeitschrift, Vol. 46, p. 703 (1925)

(64) Siemens-Ford Torsionmeter. The Engineer. Vol. 151, p. 597 (1931)

(65) E. Saunders and S. Pitre : Full-Scale Trials on a Destroyer. Transactions of the Society of Naval Architects and Engineers. Vol. 41, p. 243 (1933)

(66) Parker-Jackman: A New Design of Recording Torsion Meter. The Engineer, Vol. 142, p. 645 (1925)

(67) An Interesting New Torsionmeter. The Shipbuilder, Vol. 37, p. 539 (1930)

(68) Gehlen and H. Hoppe : Leistungsmessungen an Bord. Werft Reederei Hafen, Vol. 11, p. 421 (1930)

(69) Gehlen and H. Hoppe: Leistungsmessungen an Bord. Werft Reederei Hafen, Vol. 12, p. 38 (1931)

(70) G. Kempf: Measurements of the Propulsive and Structural Characteristics of Ships. Transactions of the Society of Naval Architects and Marine Engineers, Vol. 40, p. 45 (1932)

(71) T. Kobayashi : Application of the Inverse Wiedemann Effect to Torque Measurements and to Torque Variation Recordings. Report of the Aeronautical Research Institute, Tokyo Imperial University. 425 (1929), 1 (1930)

（72）金尾忠義：新案㹉れ動力計に就 $\tau ，$ 機械学会誌，33巻159号 (昭和 5 年)

(73) A. Gramberg: Technische Messungen 1 (1933)

（74）研野作一：研野式据計，造船協会々報, 54 号 (昭和 9 年10月)

(75) S. Togino: Optical Torsionmeter. Congrès Inter. des Direct. de Bassins, Paris, Oct. (1935)

（76）矼野作一: 研野式光学㹉計, 精密機械, 3 卷 6 号 (昭和11年 10月)

(77) S. Togino: The Latest Type of Togino's Optical Torsionmeter. Abstract Notes and Data concerning the Subjects at the Six International Conference of Ship Tank Superintendents, 64 (1951)

（78）松本英一：松本式㨝り動力計,日本光学工業会社(昭和10年)

（79）谷下市松：動力测定（岩波講座, 機械工学）(昭和17年)

（80）浜部源次郎, 長尾不二夫, 渡辺輝雄: 新据り動力計, 機械学 会論文集, 1 巻 3 号 (昭和 10 年 8 月)

(81) J. Müller : Stroboscopic Measurement of Toque and Torsional Vibration in Ship's Propeller Shafting. Transactions of the Society of Naval Architects and Marine Engineers, Vol. 43, p. 241 (1935)

（82）濑藤象二：㹉れ動力計，電気学会連合大会予稿（昭和13年 4 月)

（83）上野亨: 誘型発電機を応用せる据り動力計, 電気評論, 31 巻 8 号 (昭和 18 年 8 月)

（84）近鹿晴男: 籠形誘導電動機トルク一速度测定装置, 電気学 会連合大学予稿（昭和13年 4 月）

(85) Direct Reading S. H. P. Meter. Shipbuilding and Shipping Record, Vol. 51, p. 755 (1938)

(86) New Meter for Measuring Shaft Horse-Power. The Marine Engineer, Vol. 62, p. 208 (1939)

(87) Meter for Measuring Shaft Horse Power. Marine Engineering and Shipping Review, Vol.44, p. 176 (1939)

(88) A. V. Merchon and A. L. Ruiz: The General Electric Marine Shaft Horsepower-Hour Meter. Marine Engineering and Shipping Review. Vol. 56 , p. 45 , June (1951)

(89) Marine Shaft Horsepower-Hour Meter Successfully Tested. Marine Engineering and Shipping Review. Vol. 56, p. 75, April (1951)
(90) G. E. Shaft Horsepower Hour Meter in Successful Test. Motorship, Vol. 36, p. 35, April (1951)

(91) Marine Shaft Horsepower Meter. Marine Engineering and Shipping Review, Vol. 55, p. 76, Feb. (1950)

(92) Propeller Shaft Torque Instrumentation. General Electric Instrmentation Book, Industry Control Department

（93）海老原敬吉：压電気を応用せる据り動力計，機械学会論文 集, 6 卷22号 (昭和15年 2 月)

(94) W.C. Hall: A New Type of Power-Torque Meter. Oransactions of the Society of Naval Architects and Marine Engines, Vol. 48, p. 320 (1940)

(95) W.C. Hall: A New Type of Power-Torque Meter The Engineer, Vol. 171, p. 119 (1940)

(96) R. Gunn: A Convenient Electrical Micrometer and its Use in Mechanical Measurements. Journal of Applied Mchanics, 7, A-49 (1940)

(97) R. Cook: Marine Torsionmeters and Thrustmeters. Transactions of The Institute of Marine Engineers, Vol. 7, p. 115 (1951)

(98) A.C. Ruge: The Bonded Wire Gauge Torquemeter. Proceeding of Soc. Exp. Stress Anal, Vol. 1, p. 2, 68 (1943)

(99) F. W. Godsey and B. F. Langer : Aircraft-Engine Torque Instruments. Trans. Americal Society of Electrical Engineers, Vol. 63, p. 686 (1944)

(100) B.F. Langer: Measurement of Torque Transmitted by Rotating Shafts. Joural of Applied Mechanics, 12, A-39 (1945)

(101) F. Aughtie: Electrical Resistance Wire Strain Gauges. Proceeding of Mechanical Engineers, Vol. 152, p. 213 (1945)

(102) Code on Instruments and Apparatus for Ship Trials. The Society of Naval Architects and Marine Engineers (1952)

(103) The Measurement of Torsion, Shaft Power Thrust and Specific Fuel Consumption on Board Ships. Schifen Werf, Vol. 18, p. 4, 535 (1959)

(101) J. Morrison : Recent Developments in the Meas urement of Propeller Shaft Torque and Thrust. Transactions of the Institute of Marine Engineers, Vol. 78, p. 5, 193 (1966)

(105) M. Kinoshita: A New Torsionmeter of the Mag neto-Striction Type and a Shaft-Horsepower-Meter, Abstract Notes and Data concerning the Subjects at the Sixth International Conference of Ship Tank Superintendents, 55 (1951)

（106）木下昌婎, 岡田正次郎, 紊藤禎三郎: 軸馬力計の試作研究, 日立造船技報, 12 , No. 5, 18 (1951): 13, No. 1, 6 (1952)

（107）伊丹潔，伊沢省二，野村順太郎，野中淳良：電気式据り動力 計, 奄匃学会建合大会予稿 (昭和 27 年 5 月)

（108）伊丹潔: 電気式舶用箐算軸馬力計の研究，日本舶用機関学会 誌 2 巻 3 号, 111 (昭和 42 年 6 月)

（199）山口富夫：久野式据り動力計によるあらりか丸海上試運転 そ拈ける軸馬力及び据り振動の测定（昭和26年 7 月），久野 式振り動力計飞就て (昭和 25 年 7 月), 電気式直詤指示平均 有効任力計の試作, 舶用内燃機関馬力剆定の精度向上飞関 する研究 (シリンダ内压力検出装置の研究) (昭和 37 年 3 月) （以上三菱重工業神戸造船所研究報告）

（110）繁見倫一，有川正一，遠藤丘：無接触方式に上る新しい舶用 軸馬力計. 日本船用機関学会誌 2 巻 1 号, 19(昭和 42 年 2 月)

（111）谷口中, 渡边恭二: 高速艦艇用軸馬力計. 造船協会論文集, 第108易，105（喵和35年）

(112) J. Bell : Digital Technique Measures Ship's Horse power. Electronics, Vol. 17, p. 142, Nov. (1961)

(113) Orvar Dahle: The Ring Transducer-a Torque Transducer, without Slip Rings, for Industrial Measurement and Control. ASEA Journal Vol, 33, p. 23 (1960)

（114）寺山進, 別所皓二，鈴木春夫：無接触方式に上る新しい舶用 軸馬力計，日本舶用機関学会誌 2 巻 4 号， 180 (沼和 42 年 8 月)

(115) V.W.H. Towns: Developments in the Measurement of Torque and Thrust in Ships. The Institute of Marine Engineers, Vol. 47, p. 11 (1935) 